\title{
Zirconia/Hydroxyapatite Composites Synthesized Via Sol-Gel: Influence of Hydroxyapatite Content and Heating on Their Biological Properties
}

\author{
Flavia Bollino ${ }^{1, *}$, Emilia Armenia ${ }^{2}$ and Elisabetta Tranquillo ${ }^{1}$ \\ 1 Department of Industrial and Information Engineering, University of Campania "Luigi Vanvitelli", \\ 81031 Aversa, Italy; elisabetta.tranquillo@unicampania.it \\ 2 Department of Cardiothoracic and Respiratory Sciences, University of Campania "Luigi Vanvitelli", \\ 80131 Naples, Italy; emiliaarmenia@hotmail.it \\ * Correspondence: flavia.bollino@unina2.it; Tel.: +39-081-501-0483
}

Academic Editor: Michelina Catauro

Received: 17 May 2017; Accepted: 30 June 2017; Published: 5 July 2017

\begin{abstract}
Zirconia $\left(\mathrm{ZrO}_{2}\right)$ and zirconia-based glasses and ceramics are materials proposed for use in the dental and orthopedic fields. In this work, $\mathrm{ZrO}_{2}$ glass was modified by adding different amounts of bioactive and biocompatible hydroxyapatite (HAp). $\mathrm{ZrO}_{2} / \mathrm{HAp}$ composites were synthesized via the sol-gel method and heated to different temperatures to induce modifications of their chemical structure, as ascertained by Fourier transform infrared spectroscopy (FTIR) analysis. The aim was to investigate the effect of both HAp content and heating on the biological performances of $\mathrm{ZrO}_{2}$. The materials' bioactivity was studied by soaking samples in a simulated body fluid (SBF). FTIR and scanning electron microscopy (SEM)) analyses carried out after exposure to SBF showed that all materials are bioactive, i.e., they are able to form a hydroxyapatite layer on their surface. Moreover, the samples were soaked in a solution containing bovine serum albumin (BSA). FTIR analysis proved that the synthesized materials are able to adsorb the blood protein, the first step of cell adhesion. WST-8 ([2-(2-methoxy-4-nitrophenyl)-3-(4-nitrophenyl)-5-(2,4-disulfophenyl)-2H-tetrazolium, monosodium salt]) assay showed that no cytotoxicity effects were induced by the materials' extract. However, the results proved that bioactivity increases with both the HAp content and the temperature used for the thermal treatment, whereas biocompatibility increases with heating but is not affected by the HAp content.
\end{abstract}

Keywords: sol-gel method; Fourier transform infrared spectroscopy (FTIR) analysis; bioactivity; biocompatibility

\section{Introduction}

Zirconia and zirconia-based glasses and ceramics have attracted considerable interest as materials to be used in the biomedical field [1-5]. In vivo and in vitro studies showed that zirconia and zirconia-based glasses and ceramics do not induce any cytotoxicity effects in either soft or hard tissue [3,5]. When a zirconia prosthesis was implanted in vivo, it was encapsulated by connective tissue, and thus any local or systemic toxic effect was not recorded after its insertion [3,5]. However, although zirconia is well tolerated, it is a bioinert material, as it does not show either the ability of direct bone bonding or osteoconduction behavior. Moreover, release of residues or degradation phenomena of zirconia implants were not detected and a low bacterial growth was observed $[3,5]$. In addition to these biological properties, the good mechanical behavior of zirconia has stimulated the interest of researchers in the biomaterials field. $\mathrm{ZrO}_{2}$ is an oxide which presents three types of crystalline structures at ambient pressure: (i) the monoclinic phase $\left(\mathrm{m}-\mathrm{ZrO}_{2}\right)$, which is stable from 
room temperature up to $1170{ }^{\circ} \mathrm{C}$ and exhibits poor mechanical properties; (ii) the tetragonal phase $\left(\mathrm{t}-\mathrm{ZrO}_{2}\right)$, which is stable in the temperature range $1170-2370{ }^{\circ} \mathrm{C}$ and has good mechanical properties; and (iii) the cubic phase $\left(\mathrm{c}-\mathrm{ZrO}_{2}\right)$, which is stable above $2370{ }^{\circ} \mathrm{C}$ and has moderate mechanical properties [6-8]. In order to stabilize the tetragonal phase at room temperature, zirconia can be mixed with other metallic oxides (e.g., $\mathrm{MgO}, \mathrm{La}_{2} \mathrm{O}_{3}, \mathrm{CaO}, \mathrm{Y}_{2} \mathrm{O}_{3}$ ) to obtain strong ceramics. Among such materials, yttrium-stabilized zirconia (known as tetragonal zirconia polycrystal (TZP)) is one of the most studied [9]. As their mechanical properties, such as resistance to traction and compression resistance, are similar to those of metals (e.g., stainless steel) [10], and they have good biocompatibility, zirconia and zirconia-based ceramics were first used in orthopedics as a substitute for titanium and alumina in hip head prostheses [11]. Afterwards, they were successfully used in dentistry, where they are still considered to be a material of choice for root canal posts, fixed partial dentures, and dental implants [12]. Moreover, some studies [13-16] report the use of TZP as fillers to reinforce the mechanical properties of synthetic hydroxyapatite (HAp) (a biodegradable and biocompatible calcium phosphate ceramic with a bone-like structure, capable of forming strong chemical bonds with natural bone tissue [17]). Other studies investigated the use of zirconia-based glasses, synthesized via the sol-gel method, as drug delivery systems $[2,18]$ or as coatings capable of improving the biological performance of titanium implants [19-22]. Zirconia-based glasses, synthesized by means of the sol-gel method, showed the ability to slightly improve cell viability of the human osteosarcoma cell line (SAOS-2) [20] and human mesenchymal stromal cells (hMSCs) [22]. This is ascribable mainly to the preparation method. The sol-gel technique, indeed, is a versatile process used to make glass and ceramic materials at low temperature, and has been extensively used to prepare a wide variety of materials with different applications, including the bioglass [23-27]. The process starts from a solution of metal alkoxide or metal salt precursors in water-alcohol and involves their hydrolysis and condensation reactions, which lead to the formation of a 3D rigid gel [28]. By drying the obtained wet gel, it is possible to prepare xerogels (by exposure to low temperatures), aerogels (by solvent extraction under supercritical conditions), or dense ceramics and glasses by means of a further heat treatment at higher temperatures. Glasses and ceramics synthesized via the sol-gel method exhibit higher bioactivity and biocompatibility than materials with the same composition but prepared by melt-quenching [29-31]. Sol-gel-derived glasses have an inherent mesoporosity that gives them a larger surface area and potentially more rapid degradation rates than melt-derived glasses of a similar composition. Moreover, the presence of $-\mathrm{OH}$ groups on their surface stimulates hydroxyapatite nucleation, promoting easier osseointegration.

The aim of the present study has been to synthesize zirconia-based composites containing different amounts of $\mathrm{HAp}\left(\mathrm{xZrO}_{2}(1-\mathrm{x}) \mathrm{HAp}\right.$, with $\mathrm{x}=$ no stabilized $\mathrm{ZrO}_{2}$ mole fraction) via the sol-gel method in order to investigate the influence of the biocompatible and bioactive HAp on the biological response of the synthesized composites. Moreover, it is known $[32,33]$ that both sol-gel zirconia and HAp glasses can crystallize by heating, leading to different crystalline phases. Therefore, the gel materials were heated at $120^{\circ} \mathrm{C}, 600^{\circ} \mathrm{C}$, and $1000^{\circ} \mathrm{C}$ to induce phase transformation and, in turn, to study the effect of thermal treatment on the biological response of the obtained materials. The choice of the temperature has been based on published studies [32,33]. Fourier transform infrared spectroscopy (FTIR) analysis was carried out to follow the materials' structural modification, induced by both HAp addition and heating. Moreover, bioactivity and biocompatibility of all samples were studied by in vitro preliminary tests after the different thermal treatments.

\section{Results and Discussion}

\subsection{Chemical Characterization}

The heat treatments of $\mathrm{ZrO}_{2}$ and $\mathrm{xZrO}_{2} \cdot(1-\mathrm{x}) \mathrm{HAp}$ gels led to transformations visible to the naked eye. The samples heated to $120{ }^{\circ} \mathrm{C}$ are yellow. After heating to $600{ }^{\circ} \mathrm{C}$ they became black, whereas after heating to $1000^{\circ} \mathrm{C}$ the powders became white, according to literature [34,35]. The change 
in the sample color is ascribable to the transformation of the $\mathrm{ZrO}_{2}$ structure induced by heating and studied by $[35,36]$ X-ray diffraction (XRD) and thermal analyses of zirconia, as reported in the literature [32,35-37]. It was shown that Acetil Acetone (AcAc)-containing zirconia, synthesized via the sol-gel method, is an amorphous and yellow-brown material, because a complex between the zirconium and the AcAc is formed in the sol phase, which exhibits strong absorption in the UV region and low-intensity absorption in the visible spectral region [38].

The increase in temperature leads to the condensation of surface -OH groups with the formation of $\mathrm{H}_{2} \mathrm{O}$. The sites involved in this reaction are also the sites for the promotion of the nucleus formation of the tetragonal phase. At about $400{ }^{\circ} \mathrm{C}$, the tetragonal phase begins to crystallize [32,37] and the material gradually darkens [34,35]. At $600{ }^{\circ} \mathrm{C}$ the material is entirely converted into the tetragonal phase $\left(\mathrm{t}-\mathrm{ZrO}_{2}\right)$ and it appears completely black $[34,35]$. This phenomenon is correlated to the formation of defects in the material, according to Wachsmanet al. [35]. The dihydroxylation process, which takes place on the material's surface above $100{ }^{\circ} \mathrm{C}$, leads to oxygen surface desorption and, thus, to the formation of oxygen vacancies [32]. The gradual transformation of $\mathrm{t}-\mathrm{ZrO}_{2}$ into the monoclinic phase $\left(\mathrm{m}-\mathrm{ZrO}_{2}\right)$ occurs $[32,37]$ when the temperature is further increased. Therefore, when the material was heat treated at $1000{ }^{\circ} \mathrm{C}$, it was transformed completely into the monoclinic structure and appears white, indicating a lack of oxygen vacancies, as reported by Wachsman et al. [35].

Despite the fact that HAp appears as a white powder regardless of the temperature used for heat treatment, the $\mathrm{xZrO}_{2} \cdot(1-\mathrm{x}) \mathrm{HAp}$ composites retain the zirconia color variations. To follow the material transformations induced by heating, FTIR analysis of all samples was carried out as a function of the temperature (Figures 1-3).

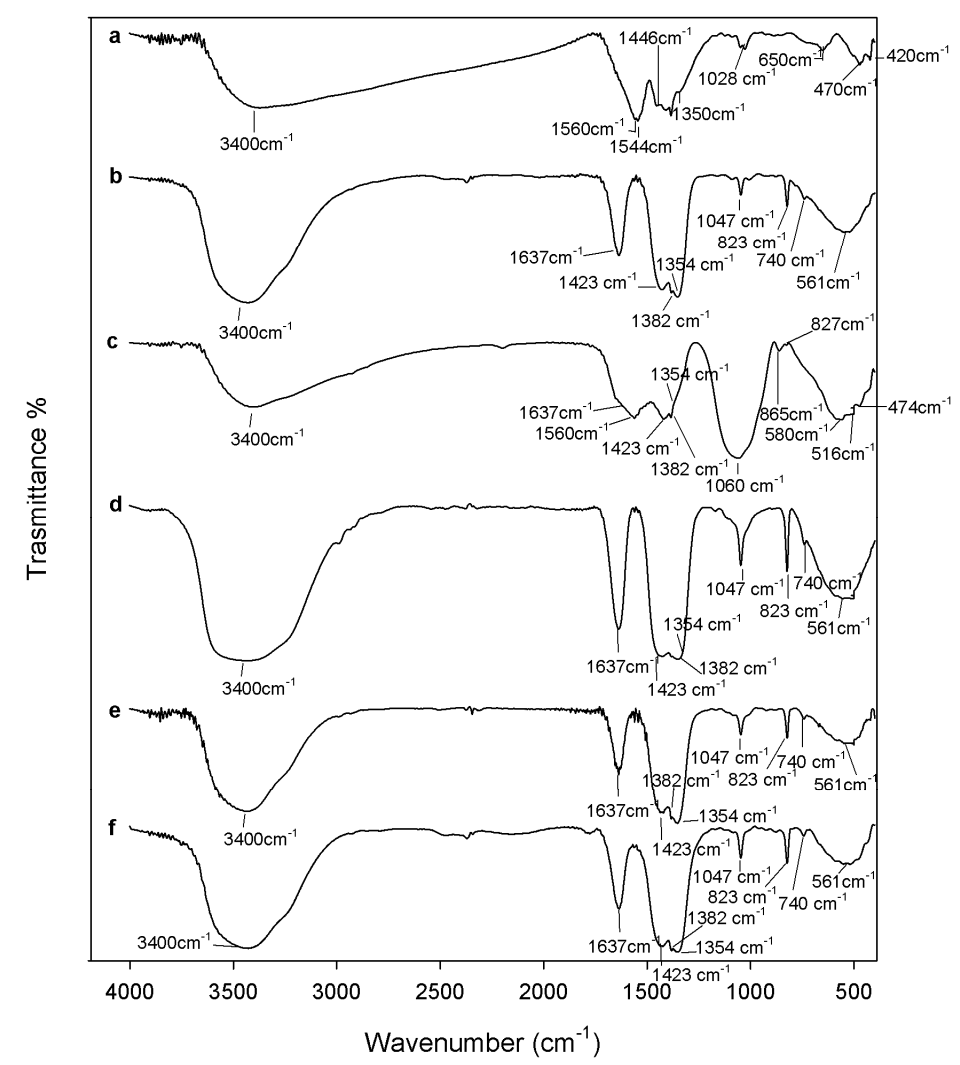

Figure 1. Fourier transform infrared spectroscopy (FTIR) of (a) $\mathrm{ZrO}_{2}$; (b) hydroxyapatite (Hap); (c) $9 \mathrm{ZrO}_{2} \cdot 1 \mathrm{Hap}$; (d) $7 \mathrm{ZrO}_{2} \cdot 3 \mathrm{Hap}$; and (e) $5 \mathrm{ZrO}_{2} \cdot 5 \mathrm{HAp}$ gels, heated to $120^{\circ} \mathrm{C}$ and (f) $\mathrm{Ca}\left(\mathrm{NO}_{3}\right)_{2} 4 \mathrm{H}_{2} \mathrm{O}$.

Figure 1 shows the FTIR spectra of all samples after drying at $120^{\circ} \mathrm{C}$. The FTIR spectrum of $\mathrm{ZrO}_{2}$ after $120^{\circ} \mathrm{C}$ heating (Figure 2a) shows all peaks typical of amorphous acetyl acetone (AcAc) containing 
zirconia sol-gel materials [36,39]. The broad intense band at $3400 \mathrm{~cm}^{-1}$ is due to the vibrations of $-\mathrm{OH}$ groups in both physically bonded water and $\mathrm{Zr}-\mathrm{OH}$ groups in the matrix. Moreover, the bands observed at $1560 \mathrm{~cm}^{-1}$ and $1446 \mathrm{~cm}^{-1}$ are assigned to $\mathrm{C}=\mathrm{O}$ vibrations of AcAc bidentate binding. The bands at $1544 \mathrm{~cm}^{-1}$ and $1350 \mathrm{~cm}^{-1}$ are due to $C-C$ vibrations. The peaks at $1028 \mathrm{~cm}^{-1}$ are assigned to $\mathrm{C}-\mathrm{C}-\mathrm{H}$ bending, mixed with stretching $\mathrm{C}-\mathrm{C}$ vibrations of AcAc [39]. The bands at $650 \mathrm{~cm}^{-1}$ and $470 \mathrm{~cm}^{-1}$ are due to $\mathrm{Zr}-\mathrm{OH}$ and $\mathrm{Zr}-\mathrm{O}-\mathrm{Zr}$ stretching, respectively $[40,41]$, whereas the peak at $420 \mathrm{~cm}^{-1}$ is attributed to $\mathrm{Zr}-\mathrm{OAcAc}$ vibrations [39].

The spectrum of HAp after $120{ }^{\circ} \mathrm{C}$ heating (Figure $1 \mathrm{~b}$ ) is very similar to the calcium nitrate spectrum (Figure 1f). Only the bands of the $-\mathrm{OH}$ stretching and banding (at $3400 \mathrm{~cm}^{-1}$ and $1637 \mathrm{~cm}^{-1}$ respectively), in the adsorbed water and of nitrate vibrations are visible, such as the signals related to asymmetric and symmetric stretching of nitrate ions at 1423, 1382, and $1354 \mathrm{~cm}^{-1}$ [42], the sharp peaks at 1047, $823 \mathrm{~cm}^{-1}$, and the weak peak at $738 \mathrm{~cm}^{-1}$, ascribable to the bending modes of the nitrate ions [42]. Calcium nitrate, indeed, was soluble in the sol and it remained in solution as the particles formed and coalesced. During drying at $120^{\circ} \mathrm{C}$, calcium nitrate coats the formed particles, therefore only the signals of the salt are visible, while those of the phosphate are masked. Only after the thermal degradation of nitrate ions (at temperatures over $500{ }^{\circ} \mathrm{C}$ [30]) does the calcium enter the network by diffusion, and the nitrate by-products are driven off. Therefore, a cleavage of the bridging oxygen bonds and the formation of non-oxygen bonds (and thus, ionic-crosslinkage with $\mathrm{Ca}^{2+}$ ions) occurs in the glass network $[30,43,44]$. Also, Catauro et al. [45] observed a similar phenomenon in $\mathrm{SiO}_{2}-\mathrm{CaO}-\mathrm{P}_{2} \mathrm{O}_{5}$ ternary systems synthesized via sol-gel, where calcium nitrate was used as precursor of the $\mathrm{CaO}$ phase. The FTIR spectra of the materials dried at $120^{\circ} \mathrm{C}$ were dominated by nitrate signals. However, the authors proved the presence of the silica and phosphate phases by FTIR analysis of the materials after soaking in a water solution. Only the signals of the silica and phosphate phases, and no signals of nitrates, were visible in the spectra. Moreover, IC analysis of the water solution showed that nitrate ions were released.

For the same reason the spectra of $0.7 \mathrm{ZrO}_{2} \cdot 0.3 \mathrm{HAp}$ and $0.5 \mathrm{ZrO}_{2} \cdot 0.5 \mathrm{HAp}$ samples (Figure $1 \mathrm{~d}, \mathrm{e}$ ) are also very similar to the $\mathrm{Ca}\left(\mathrm{NO}_{3}\right)_{2} \cdot 4 \mathrm{H}_{2} \mathrm{O}$ spectrum, whereas the spectrum of the $0.9 \mathrm{ZrO}_{2} \cdot 0.1 \mathrm{HAp}$ (Figure 1c) sample also shows signals, due to $\mathrm{ZrO}_{2}$ and the phosphate phase. In particular, two intense bands are still visible in the region $1700-1300 \mathrm{~cm}^{-1}$, but with some differences in the shape and position compared to the $\mathrm{ZrO}_{2}$ spectrum. This can be due to the influence of: (i) nitrate vibrations in the region $1500-1300 \mathrm{~cm}^{-1}$, which also cause the appearance of the weak peak at $827 \mathrm{~cm}^{-1}$ [42]; and (ii) vibrations of carbonate ions not incorporated in the apatitic structure, in the region $1500-1400 \mathrm{~cm}^{-1}$ [46]. The presence of carbonate ions, due to the solubilization of atmospheric $\mathrm{CO}_{2}$ in the sol, is also proved by the presence of the weak peak at $865 \mathrm{~cm}^{-1}[14,45,46]$. Moreover, (iii) it can be hypothesized that a new complex between calcium ions and AcAc in the sol phase is formed, and originates IR bands in the same region. It has been reported in literature [47], indeed, that calcium bis(acetylacetonate) is synthesized by adding calcium nitrate tetrahydrate and AcAc to an aqueous solution of ammonium hydroxide, which are reagents present in the sol of the $\mathrm{xZrO}_{2} \cdot(1-\mathrm{x}) \mathrm{HAp}$ composites. Moreover, the intense band at $1060 \mathrm{~cm}^{-1}$ (ascribable to $\mathrm{PO}_{4}{ }^{3-}$ vibration $[13,45,48,49]$ ) and the broad band in the region $750-400 \mathrm{~cm}^{-1}$ suggest that an amorphous calcium phosphate was formed [46,50]. The presence of the $\mathrm{PO}_{4}{ }^{3-}$ vibration suggests that in this material the calcium nitrate does not coat the glass network. It can be explained by the formation of the complex between calcium ions and AcAc, which subtracts the $\mathrm{Ca}^{2+}$ ions by the solution, reducing the interaction between nitrate ions and the glass network. As in the $0.9 \mathrm{ZrO}_{2} \cdot 0.1 \mathrm{HAp}$ sample, a lower ratio between the amount of $\mathrm{HAp}$ and $\mathrm{ZrO}_{2}$ is present; a higher ratio $\mathrm{AcAc} / \mathrm{Ca}\left(\mathrm{NO}_{3}\right)_{2} \cdot 4 \mathrm{H}_{2} \mathrm{O}$ was present in the sol of this sample, compared to the other samples. Therefore, a higher amount of the Ca-AcAc complex was formed.

Figure 2 shows FTIR spectra of all samples after heating at $600{ }^{\circ} \mathrm{C}$. In the FTIR spectrum of $\mathrm{ZrO}_{2}$ (Figure 2a) the peaks related to AcAc disappear due to its degradation [51], while sharp peaks in the region (generally assigned to the vibrations of $\mathrm{Zr}-\mathrm{O}-\mathrm{Zr}$ and $\mathrm{Zr}-\mathrm{OH}$ bonds in a crystalline structure) appear [52,53], such as those at 780, 578, 499, and $430 \mathrm{~cm}^{-1}$. 


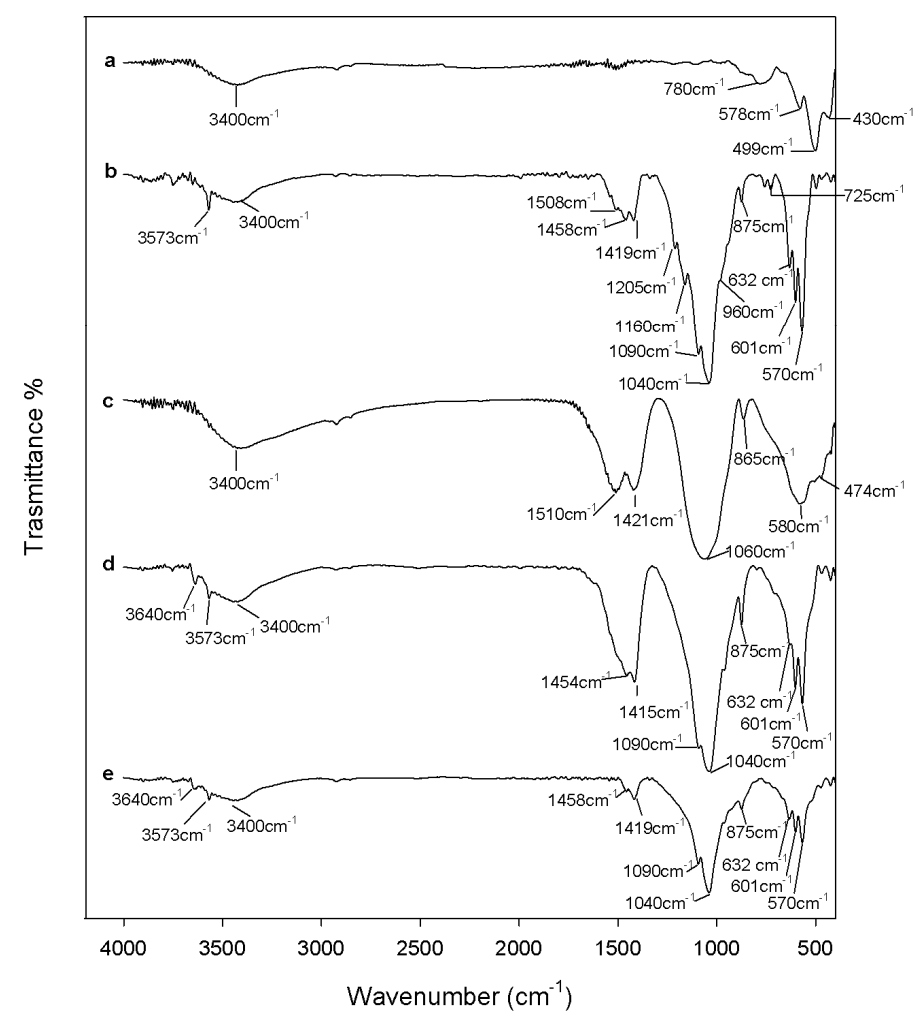

Figure 2. FTIR of (a) $\mathrm{ZrO}_{2}$; (b) Hap; (c) $9 \mathrm{ZrO}_{2} \cdot 1 \mathrm{Hap}$; (d) $7 \mathrm{ZrO}_{2} \cdot 3 \mathrm{Hap}$; and (e) $5 \mathrm{ZrO}_{2} \cdot 5 \mathrm{HAp}$ gels, heated to $600^{\circ} \mathrm{C}$.

After $600{ }^{\circ} \mathrm{C}$ heating, degradation of the nitrate ions occurs and calcium ions enter into the network by diffusion [30]. Therefore, the spectra of $\mathrm{HAp}$, of $0.7 \mathrm{ZrO}_{2} \cdot 0.3 \mathrm{Hap}$, and of $0.5 \mathrm{ZrO}_{2} \cdot 0.5 \mathrm{HAp}$ composites (Figure $2 b, d, e)$ completely change shape. In particular, FTIR analysis confirms that pure HAp was obtained (Figure 2b). All hydroxyapatite typical peaks, indeed, are visible. The intense bands at 1090 and $1040 \mathrm{~cm}^{-1}$, as well as the shoulder at $960 \mathrm{~cm}^{-1}$, are due to asymmetric and symmetric stretching in $\mathrm{PO}_{4}{ }^{3-}$ ions, respectively. The doublet at 601 and $570 \mathrm{~cm}^{-1}$ is due to phosphate bending modes and the sharp peaks at 3573 and $632 \mathrm{~cm}^{-1}$ are assigned to stretching and wagging vibrations of $-\mathrm{OH}$ groups in the crystalline apatite structure $[14,54]$. However, a calcium-deficient hydroxyapatite was obtained as proven by the signals of $\mathrm{CO}_{3}{ }^{2-}$ and $\mathrm{HPO}_{4}{ }^{2-}$ ions. In particular, the broad band in the range $1500-1400 \mathrm{~cm}^{-1}$ and the weak peak at $875 \mathrm{~cm}^{-1}$ are assigned to stretching and bending in the $\mathrm{CO}_{3}{ }^{2-}$ ions, which can substitute $\mathrm{OH}^{-}$(type A substitution) or $\mathrm{PO}_{4}{ }^{3-}$ ions (more commune type B substitution) [54]. The signal at $875 \mathrm{~cm}^{-1}$ can also be ascribed to the presence of $\mathrm{HPO}_{4}{ }^{2-}$ that characterizes the non-stoichiometric HAp and indicates the formation of anhydrous dicalcium phosphate (DCPA, $\mathrm{Ca}_{2} \mathrm{HPO}_{4}$ ) [54,55]. As the two signals overlap, it is generally difficult to distinguish between $\mathrm{CO}_{3}{ }^{2-}$ and $\mathrm{HPO}_{4}{ }^{2-}$ groups. However, in the recorded HAp spectrum, the sharp peaks at $1205 \mathrm{~cm}^{-1}, 1160 \mathrm{~cm}^{-1}$, and $725 \mathrm{~cm}^{-1}$ confirm the formation of DCPA. Those peaks, indeed, are due to the $\mathrm{P}-\mathrm{O}$ vibrations in pyrophosphate ions, which originate by the condensation of two $\mathrm{HPO}_{4}{ }^{2-}$ to $\mathrm{P}_{2} \mathrm{O}_{7}{ }^{4-}[55,56]$. The spectra of $0.7 \mathrm{ZrO}_{2} \cdot 0.3 \mathrm{HAp}$ and $0.5 \mathrm{ZrO}_{2} \cdot 0.5 \mathrm{HAp}$ composites (Figure $2 \mathrm{~d}, \mathrm{e}$ ) show the typical signals of carbonated HAp, but the carbonate bands have a different shape and intensity. The shape of this band mainly depends on the presence of "non-apatitic" or "apatitic" $\mathrm{CO}_{3}{ }^{2-}$ ions, and in the latter case, on the substitution type in the HAp lattice (A or B type) [46]. The complexity of this band in the HAp spectrum (Figure 2b) suggests that different types of $\mathrm{CO}_{3}{ }^{2-}$ ions are present. Generally, a doublet shape in the region $1450-1410 \mathrm{~cm}^{-1}$, coupled to a weak peak at $870-875 \mathrm{~cm}^{-1}$, is due to the vibrations of type B carbonate, whereas in the region $1450-1550 \mathrm{~cm}^{-1}$ vibrations of type A carbonate are visible, which generally are coupled with a band at $880 \mathrm{~cm}^{-1}[57,58]$. However, at 
1500 and $1420 \mathrm{~cm}^{-1}$, vibrations of non-apatitic $\mathrm{CO}_{3}{ }^{2-}$ ions are also present, coupled with a weak peak at about $866 \mathrm{~cm}^{-1}$ [58]. Therefore, in HAp samples, where peaks at $1530 \mathrm{~cm}^{-1}, 1455 \mathrm{~cm}^{-1}$, and $1415 \mathrm{~cm}^{-1}$ are distinguishable, apatitic type $A$ and $B$ carbonate ions are also present [59]. In the spectra of $0.7 \mathrm{ZrO} 2 \cdot 0.3 \mathrm{HAp}$ and $0.5 \mathrm{ZrO}_{2} \cdot 0.5 \mathrm{HAp}$ composites (Figure $2 \mathrm{~d}$,e), the typical doublet of apatitic $\mathrm{CO}_{3}{ }^{2}$ type $B$ is visible at $1455 \mathrm{~cm}^{-1}$ and $1415 \mathrm{~cm}^{-1}$ [57]. It cannot be excluded that the vibrations of $\mathrm{CaCO}_{3}$, produced by the thermal decomposition of calcium acetylacetonate [47], contribute to the increase of the doublet intensity, visible by comparing the HAp spectrum to the composite spectra and the composite spectra to each other. Its production and, thus, the band intensity, grows with zirconia content in the materials, due to the higher amount of AcAc used in the synthesis. The presence of the sharp peak at $3640 \mathrm{~cm}^{-1}$, ascribable to $-\mathrm{OH}$ stretching in calcium hydroxide, suggests that the formation of a $\mathrm{CaO}$ phase [50] also occurred in the $0.7 \mathrm{ZrO}_{2} \cdot 0.3 \mathrm{HAp}$ samples. The spectrum of the $0.9 \mathrm{ZrO}_{2} \cdot 0.1 \mathrm{HAp}$ sample (Figure $2 \mathrm{c}$ ) shows that the formation of the HAp structure still had not occurred. This can be due to the high amount of zirconia. Other works $[60,61]$ in literature reported the reduction of the HAp crystallinity extent, due to the incorporation of silica or zirconia in the HAp lattice. Therefore, not many differences are evident by comparing this spectrum to the spectra of the $120^{\circ} \mathrm{C}$ heated samples (Figure 1c), except for the position and intensity of the doublet in the region $1500-1300 \mathrm{~cm}^{-1}$. The signals are shifted to $1510 \mathrm{~cm}^{-1}$ and $1420 \mathrm{~cm}^{-1}$, and the weak peak at $865 \mathrm{~cm}^{-1}$ is still present in the spectrum. This suggests the prevalence of non-apatitic carbonate ions. Moreover, its higher intensity compared to pure $\mathrm{Hap}, 0.7 \mathrm{ZrO}_{2} \cdot 0.3 \mathrm{HAp}$ and $0.5 \mathrm{ZrO}_{2} \cdot 0.5 \mathrm{HAp}$ composites can be ascribed to the degradation of the higher calcium acetylacetonate content, due to the use of the higher amount of AcAc in the synthesis.

Figure 3 shows the FTIR spectra of all samples after $1000{ }^{\circ} \mathrm{C}$ heating. All peaks in the spectrum of the $\mathrm{ZrO}_{2}$ sample (Figure 3a) appear more intense and sharp compared to the spectrum of $\mathrm{ZrO}_{2}$ after $600^{\circ} \mathrm{C}$ heating (Figure 2a). This observation suggests that an increase of sample crystallinity occurred. Moreover, the broad weak band at $718 \mathrm{~cm}^{-1}$ was replaced by an intense peak at $748 \mathrm{~cm}^{-1}$, typical of the $\mathrm{m}-\mathrm{ZrO}_{2}$ spectrum [52].

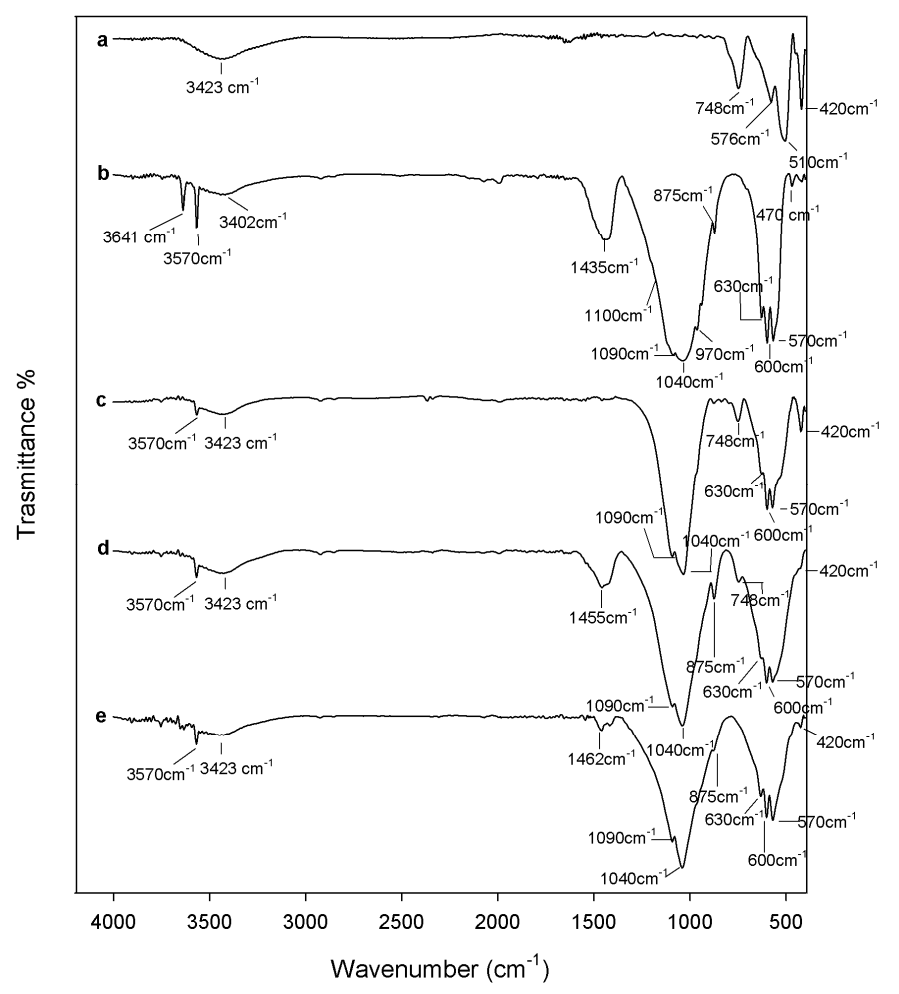

Figure 3. FTIR of (a) $\mathrm{ZrO}_{2}$; (b) Hap; (c) $9 \mathrm{ZrO}_{2} \cdot 1 \mathrm{Hap}$; (d) $7 \mathrm{ZrO}_{2} \cdot 3 \mathrm{Hap}$; and (e) $5 \mathrm{ZrO}_{2} \cdot 5 \mathrm{HAp}$ gels, heated to $1000^{\circ} \mathrm{C}$. 
After $1000^{\circ}$ heating of the pure HAp sample the degradation of DCPA occurred, as proved by the disappearance of $\mathrm{P}_{2} \mathrm{O}_{7}{ }^{4-}$ peaks from the spectrum (Figure 3b) [54-56]. It is known [62] that calcium-deficient hydroxyapatite contains hydrogen phosphate ions which condense to pyrophosphate in the temperature range $600-700{ }^{\circ} \mathrm{C}$. The pyrophosphate formed, in turn, degrades at higher temperatures producing HAp and tricalcium phosphate polymorphs $\beta$ ( $\beta-\mathrm{TCP})$. The formation of $\beta$-TCP as a secondary phase is confirmed by the shoulders at 970 and $1100 \mathrm{~cm}^{-1}$ [54]. Moreover, the carbonate peaks are still present after $1000{ }^{\circ} \mathrm{C}$ heating, but with different shapes. Part of the $\mathrm{CaCO}_{3}$, indeed, decomposes into $\mathrm{CO}_{2}$ and $\mathrm{CaO}$. The first is released as a volatile gas; the second is retained in the material, as proved by the sharp peak at $3641 \mathrm{~cm}^{-1}[50,63]$. Therefore, the single band at $1435 \mathrm{~cm}^{-1}$ and the weak peak at $875 \mathrm{~cm}^{-1}$ are ascribable to the residual apatitic $B$ type carbonate. After $1000{ }^{\circ} \mathrm{C}$ heating, the formation of $\mathrm{HAp}$ also occurred in the $0.9 \mathrm{ZrO}_{2} \cdot 0.1 \mathrm{HAp}$ sample (Figure $3 \mathrm{c}$ ), as proven by the modification of the FTIR spectrum, which assumes the typical shape of the HAp spectrum. The broad band in the region $700-400 \mathrm{~cm}^{-1}$ and the strong peak at $1060 \mathrm{~cm}^{-1}$ split, and the typical HAp doublets arise at $600-570 \mathrm{~cm}^{-1}$ and $1090-1040 \mathrm{~cm}^{-1}$, respectively. Moreover, the signal of the $-\mathrm{OH}$ groups in HAp are also visible at 3570 and $630 \mathrm{~cm}^{-1}$, whereas the carbonate signals disappear, confirming that such ions were not strictly incorporated in the materials structure (non apatitic carbonate). However, the peaks at 748 and $420 \mathrm{~cm}^{-1}$, and the shoulder at $510 \mathrm{~cm}^{-1}$, prove the presence of $\mathrm{ZrO}_{2}$ in the sample. $\mathrm{ZrO}_{2}$ peaks are still visible in the spectrum of the $1000^{\circ}$ heated $0.7 \mathrm{ZrO}_{2} \cdot 0.3 \mathrm{HAp}$ sample (Figure $3 \mathrm{~d}$ ), but with lower intensity and as shoulders, whereas they are not detectable in the spectra of the $0.5 \mathrm{ZrO}_{2} \cdot 0.5 \mathrm{HAp}$ sample (Figure 3e) because they are overlapped by $\mathrm{HAp}$ signals. In the spectra of the $1000^{\circ}$ heated $0.7 \mathrm{ZrO}_{2} \cdot 0.3 \mathrm{HAp}$ and $0.5 \mathrm{ZrO}_{2} \cdot 0.5 \mathrm{HAp}$ samples, the signal of $\mathrm{CO}_{3}{ }^{2-}$ type $\mathrm{B}$ residues are also visible. The band at $1455 \mathrm{~cm}^{-1}$ and the weak peak of $875 \mathrm{~cm}^{-1}$, indeed, are ascribable to residual apatitic carbonate $[46,50]$. Moreover, the formation of $\beta-T C P$, as a degradation product of the thermal degradation of the HAp phases, probably occurs also in those composites samples. In the literature, indeed, it is reported that zirconia can act as a catalyst of the decomposition reaction [61], which, thus, can also occur at a lower temperature [13]. However, $\beta$-TCP is undetectable in the spectra of the composites, because in those materials a lower HAp content is present which, thus, leads to the formation of a lower $\beta$-TCP amount.

\subsection{Evaluation of Biological Properties}

The biocompatibility of the synthesized samples after $600{ }^{\circ} \mathrm{C}$ and $1000^{\circ} \mathrm{C}$ heating was assessed by evaluating both the materials' ability to absorb blood proteins on their surface and the materials' cytotoxicity. The biocompatibility of the samples after $120^{\circ} \mathrm{C}$ heating was not tested, as in these samples toxic nitrate ions are present, as proved by FTIR analysis (Figure 1).

Figures 4 and 5 show FTIR spectra of all samples, heated to $600{ }^{\circ} \mathrm{C}$ and $1000{ }^{\circ} \mathrm{C}$, respectively, after $24 \mathrm{~h}$ of exposure to bovine serum albumin (BSA) solution. The comparison between sample spectra (Figure 4, curves from $b$ to e) and the BSA spectrum (Figure 4, curve a) showed that after heat treatment at $600{ }^{\circ} \mathrm{C}$, the protein adsorption is low and occurs only on the surface of $\mathrm{xZrO}_{2} \cdot(1-\mathrm{x}) \mathrm{HAp}$ composites. Indeed, the main peak of albumin at $1654 \mathrm{~cm}^{-1}$, due to the stretching of $\mathrm{C}-\mathrm{O}$ in amide I [64], is visible with low intensity only in the FTIR spectra of the samples $0.9 \mathrm{ZrO}_{2} \cdot 0.1 \mathrm{HAp}$ (as a shoulder of the band at $\left.1512 \mathrm{~cm}^{-1}\right), 0.7 \mathrm{ZrO}_{2} \cdot 0.3 \mathrm{Hap}$, and $0.5 \mathrm{ZrO}_{2} \cdot 0.5 \mathrm{HAp}$ as weak peak. 


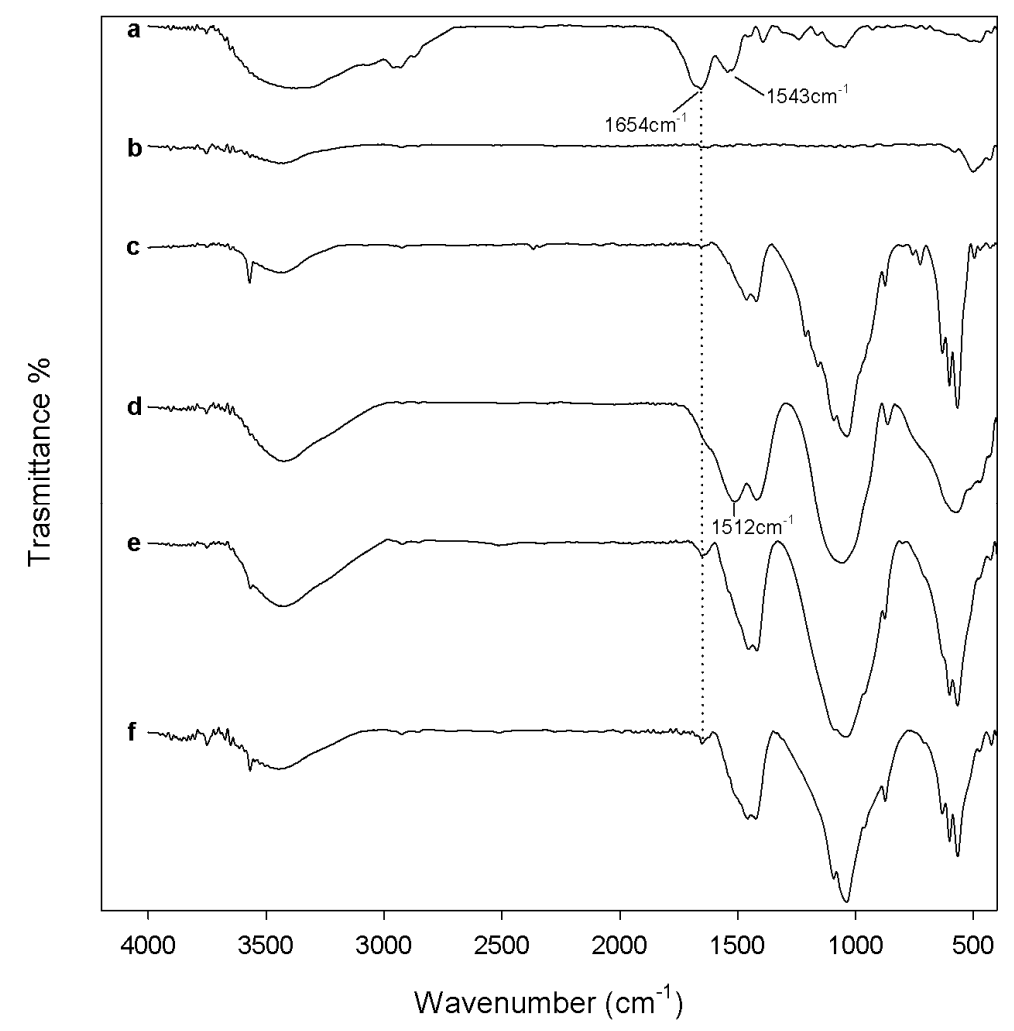

Figure 4. FTIR of (a) bovine serum albumin (BSA) and (b) $\mathrm{ZrO}_{2}$; (c) Hap; (d) $9 \mathrm{ZrO}_{2} \cdot 1 \mathrm{Hap}$; (e) $7 \mathrm{ZrO}_{2} \cdot 3 \mathrm{Hap}$; and (f) $5 \mathrm{ZrO}_{2} \cdot 5 \mathrm{HAp}$ gels, heated to $600{ }^{\circ} \mathrm{C}$, after $24 \mathrm{~h}$ of exposure to the BSA solution.

The presence of the adsorbed proteins is more evident in the samples heat-treated to $1000{ }^{\circ} \mathrm{C}$ (Figure 5). In the spectra of all samples, except in the FTIR spectrum of pure $\mathrm{ZrO}_{2}$, an increase of the intensity of the albumin band at $1654 \mathrm{~cm}^{-1}$ is visible. Moreover, in the samples of $0.5 \mathrm{ZrO}_{2} \cdot 0.5 \mathrm{HAp}$ the BSA band at $1543 \mathrm{~cm}^{-1}$ also appears, due to $\mathrm{N}-\mathrm{H}$ in-plane bending of amide II [64]. Therefore, the protein adsorption is affected by heat treatment carried out on the materials after synthesis, and is higher when the materials are heated to $1000^{\circ} \mathrm{C}$. This can be ascribed to a different degree of ions' release, from the materials heated to different temperatures. Mavropoulos et al. [65] proved that BSA adsorption on synthetic hydroxyapatite is affected by ions present in the solution containing the protein. In particular, the authors observed a decrease of the BSA adsorption with an increase of the phosphate concentration in the BSA solution. The presence of a high amount of $\mathrm{PO}_{4}{ }^{3-}$ in the diffusion layer at the HAp surface, indeed, results in an increase of the electrostatic repulsion force between HAp and BSA. Moreover, Catauro et al. [45] showed that calcium phosphates ternary systems, heated to $600{ }^{\circ} \mathrm{C}$, release a higher amount of $\mathrm{Ca}^{2+}$ and $\mathrm{PO}_{4}{ }^{3-}$ ions compared to the same materials heated at $1000{ }^{\circ} \mathrm{C}$. Therefore, the test results can be explained by a higher ion release from the materials heated to $600{ }^{\circ} \mathrm{C}$, compared to those heated to $1000{ }^{\circ} \mathrm{C}$ (which modifies the $\mathrm{pH}$ of the solution, the charges of both the materials surface, and the BSA and, thus, affects their interaction). The higher ion release observed in the sol-gel materials heated to a lower temperature is due to their lower crystallinity degree, as reported in the literature [66].

Moreover, the presence of HAp improves the $\mathrm{ZrO}_{2}$ ability of absorbing proteins. As the blood protein adsorption on the sample surface is the first step leading to cell adhesion and proliferation, the test results suggest that the materials heated to $1000{ }^{\circ} \mathrm{C}$ are more biocompatible than those heated to $600{ }^{\circ} \mathrm{C}$, regardless of the HA amount in the samples.

In order to confirm this data, WST-8 assay was carried out to evaluate material cytotoxicity. 


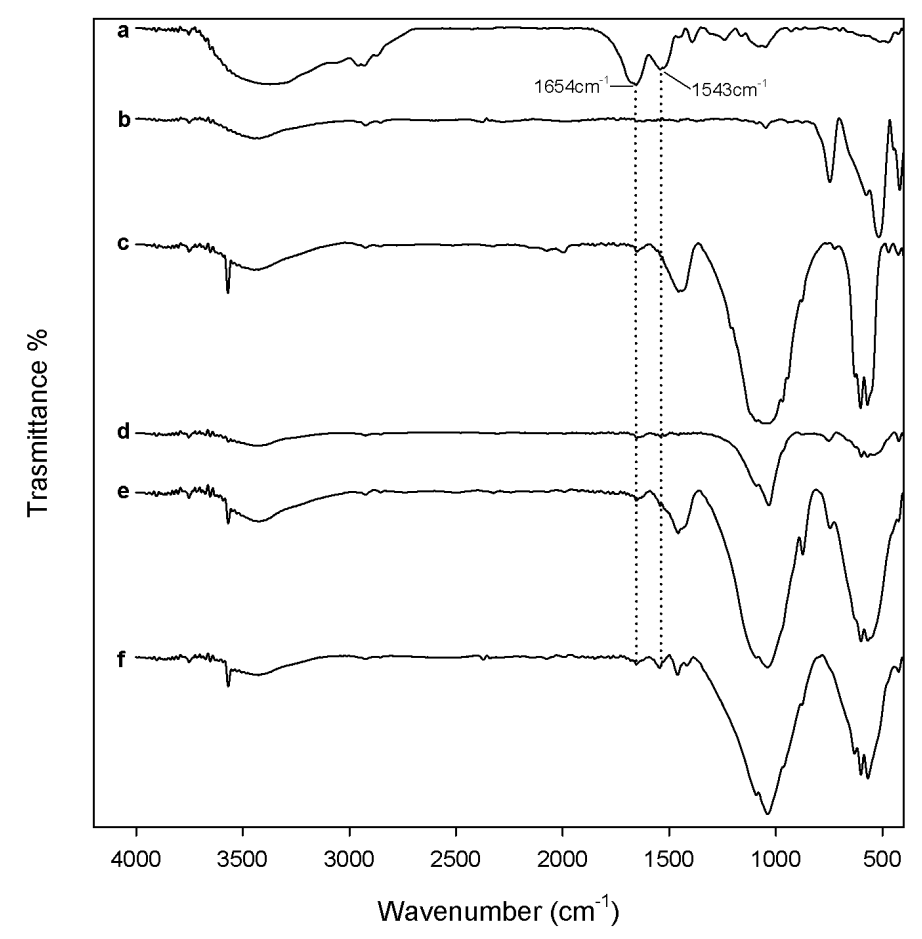

Figure 5. FTIR of (a) BSA and (b) $\mathrm{ZrO}_{2}$; (c) Hap; (d) $9 \mathrm{ZrO}_{2} \cdot 1 \mathrm{Hap}$; (e) $7 \mathrm{ZrO}_{2} \cdot 3 \mathrm{Hap}$; and (f) $5 \mathrm{ZrO}_{2} \cdot 5 \mathrm{HAp}$ gels, heated to $1000{ }^{\circ} \mathrm{C}$, after $24 \mathrm{~h}$ of exposure to BSA solution.

The results of the cytotoxicity assay are reported in Figure 6. NIH-3T3 (National Institutes of Health-3 day transfer, inoculum $3 \times 10^{5}$ cells) murine fibroblast cell line, after contact with extracts of the samples heated to $600{ }^{\circ} \mathrm{C}$, showed viability almost similar to control cells, regardless of the HAp amount. This result proves that both $600^{\circ}$-heated $\mathrm{ZrO}_{2}$ and Hap, as well as $\mathrm{xZrO}_{2} \cdot(1-\mathrm{x}) \mathrm{HAp}$ composites, are bioinert materials. An increase of cell viability with respect to the control cells was recorded after exposure to extracts of the samples heated to $1000{ }^{\circ} \mathrm{C}$.

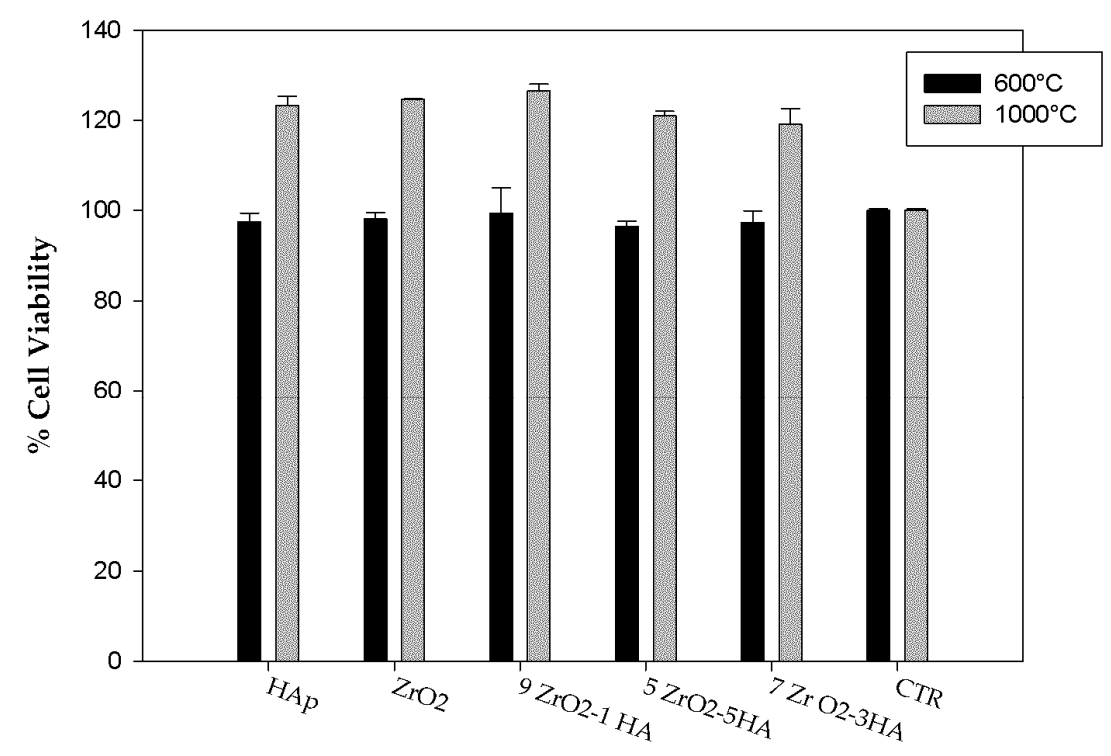

Figure 6. Cytotoxicity assay results. CTR: Control.

Therefore, the HAp content does not affect the biocompatibility of the sol-gel materials, whereas the heat treatment influences this biological property. All samples (pure $\mathrm{ZrO}_{2}$ and Hap, as well as 
$\mathrm{xZrO}_{2} \cdot(1-\mathrm{x}) \mathrm{HAp}$ composites), heated to $1000{ }^{\circ} \mathrm{C}$, are more biocompatible than those heated to $600{ }^{\circ} \mathrm{C}$, in agreement with the results of the protein adsorption test. This improvement can be due to the higher protein adsorption ability of the materials heated to $1000^{\circ} \mathrm{C}$. Moreover, as the biocompatibility improvement occurs also in pure materials $\left(\mathrm{ZrO}_{2}\right.$ and $\left.\mathrm{HAp}\right)$, it can be ascribed also to the zirconia and HAp microstructure modifications induced by heating. When the samples were heated to $1000{ }^{\circ} \mathrm{C}$, an increase of crystallinity degree occurs and $\mathrm{m}-\mathrm{ZrO}_{2}$ and TCP are formed (as proved by FTIR analysis, Figure 3), which can contribute to biocompatibility improvement of the samples. It is known, indeed, that $\mathrm{t}-\mathrm{ZrO}_{2}$ is a bioinert material with good mechanical properties used in the dental field $[1,3,5]$. However, test results showed an increase of the viability of the cells seeded on $\mathrm{m}-\mathrm{ZrO}_{2}$, suggesting that its presence makes the composites more biocompatible (Figure 6). Moreover, it is proven that TCP has higher osteoconductivity than HAp [67]. Therefore, its presence in the materials heated to $1000{ }^{\circ} \mathrm{C}$, as well as the presence of $\mathrm{m}-\mathrm{ZrO}$, can contribute to the improvement of the material's biological performance.

The osseointegration ability of the sol-gel materials was evaluated by studying their bioactivity in vitro. After soaking in SBF and drying, powders and disks of the synthesized materials after $600{ }^{\circ} \mathrm{C}$ and $1000{ }^{\circ} \mathrm{C}$ heating were analyzed by FTIR and scanning electron microscopy (SEM).

FTIR spectra of the pure HA and $\mathrm{xZrO}_{2} \cdot(1-\mathrm{x}) \mathrm{HAp}$ samples heated to $600{ }^{\circ} \mathrm{C}$, recorded after 21 days of exposure to SBF (Figure 7 curves from $b$ to e), did not show any new peak compared to the FTIR spectra of the same samples recorded before the test (Figure 2). Only an increase and a broadening of the HAp signals are visible, ascribable to the nucleation of new HAp on the samples' surfaces.

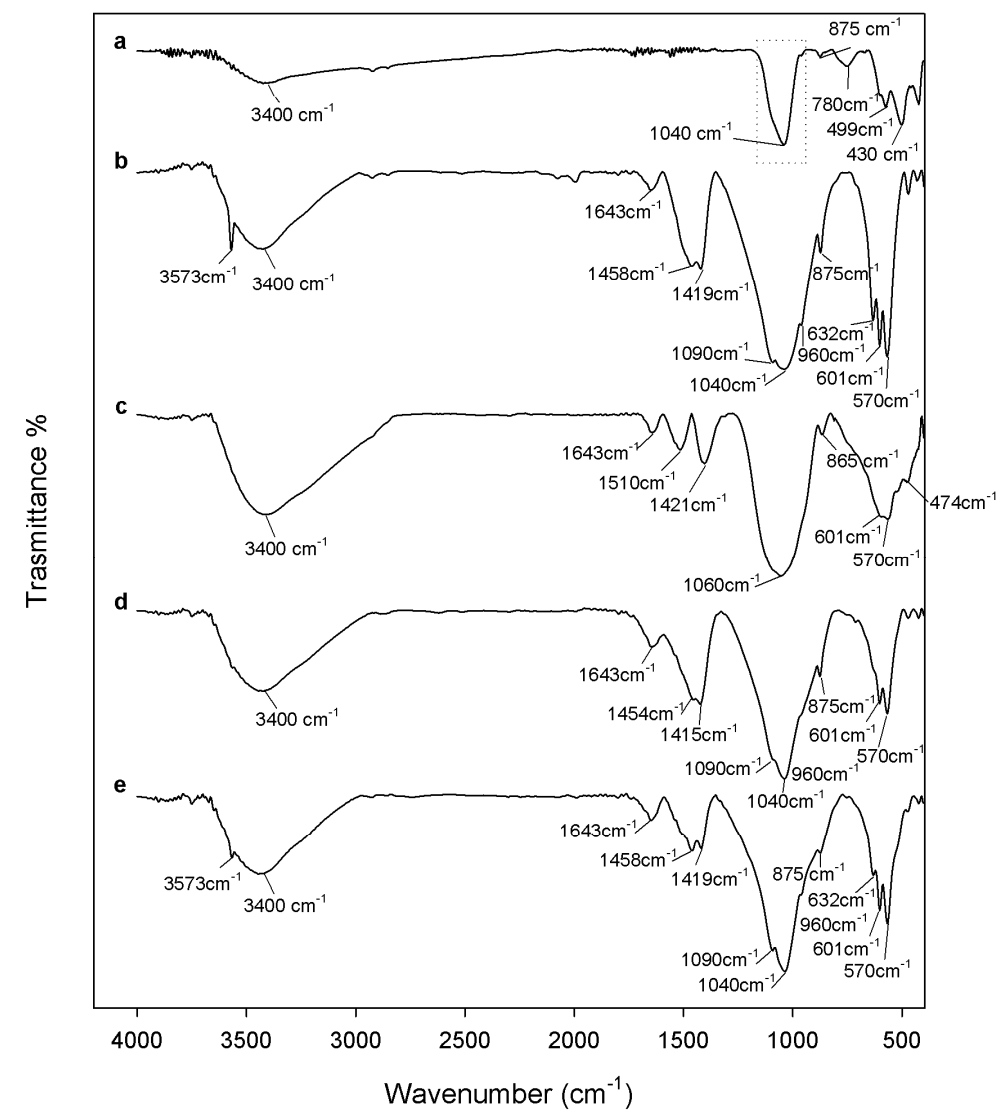

Figure 7. FTIR of (a) $\mathrm{ZrO}_{2}$; (b) Hap; (c) $9 \mathrm{ZrO}_{2} \cdot 1 \mathrm{Hap}$; (d) $7 \mathrm{ZrO}_{2} \cdot 3 \mathrm{Hap}$; and (e) $5 \mathrm{ZrO}_{2} \cdot 5 \mathrm{HAp}$ gels, heated to $600{ }^{\circ} \mathrm{C}$, after 21 days of exposure to Simulated Body Fluid (SBF).

In contrast, $\mathrm{HAp}$ nucleation on the pure $\mathrm{ZrO}_{2}$ sample (Figure 7 curve a) caused the appearance of a new intense peak at $1040 \mathrm{~cm}^{-1}$, due to P-O asymmetric stretching of the $\mathrm{PO}_{4}{ }^{3-}$ groups [54]. 
The change recorded in the spectra of the samples heated to $1000{ }^{\circ} \mathrm{C}$ after 21 days of exposure to SBF (Figure 8) are the same as those observed in the spectra of the samples heated to $600{ }^{\circ} \mathrm{C}$. Therefore, a broadening and an intensity increase of the HAp signals is observable in all sample spectra and a peak at $1040 \mathrm{~cm}^{-1}$ [54], due to $\mathrm{P}-\mathrm{O}$ asymmetric stretching in $\mathrm{PO}_{4}{ }^{3-}$ groups, is visible in the spectrum of the pure $\mathrm{ZrO}_{2}$ sample (Figure 8, curve a). Moreover, weak peaks at 1210 and $725 \mathrm{~cm}^{-1}$ are visible in the HAp spectrum (Figure 8, curve b), which can be assigned to P-O vibrations in pyrophosphate groups. The presence of pyrophosphate ion inclusions in the hydroxyapatite nucleated on the surface of the synthesized HAp can be due to the dissolution of the $\beta$-TCP (its formation was proved by FTIR analysis, Figure 3 curve b) in Simulated Body Fluid (SBF), which leads to the formation of $\mathrm{HPO}_{4}{ }^{-2}$, $\mathrm{PO}_{4}{ }^{-3}$, and $\mathrm{OH}^{-}$ions [68]. As in the $\mathrm{xZrO}_{2} \cdot(1-\mathrm{x}) \mathrm{HAp}$ composites, the amount of HAp is lower, while the content of $\beta$-TCP formed by HAp thermal decomposition is also lower than that present in HAp. Therefore, pyrophosphate signals are not visible in the composite spectra.

The presence of the carbonate signals proves that calcium-deficient hydroxyapatite was grown on the surface of all synthesized samples. The carbonatation is higher in the $600{ }^{\circ} \mathrm{C}$ heated samples, i.e., their spectra carbonate signals are more evident.

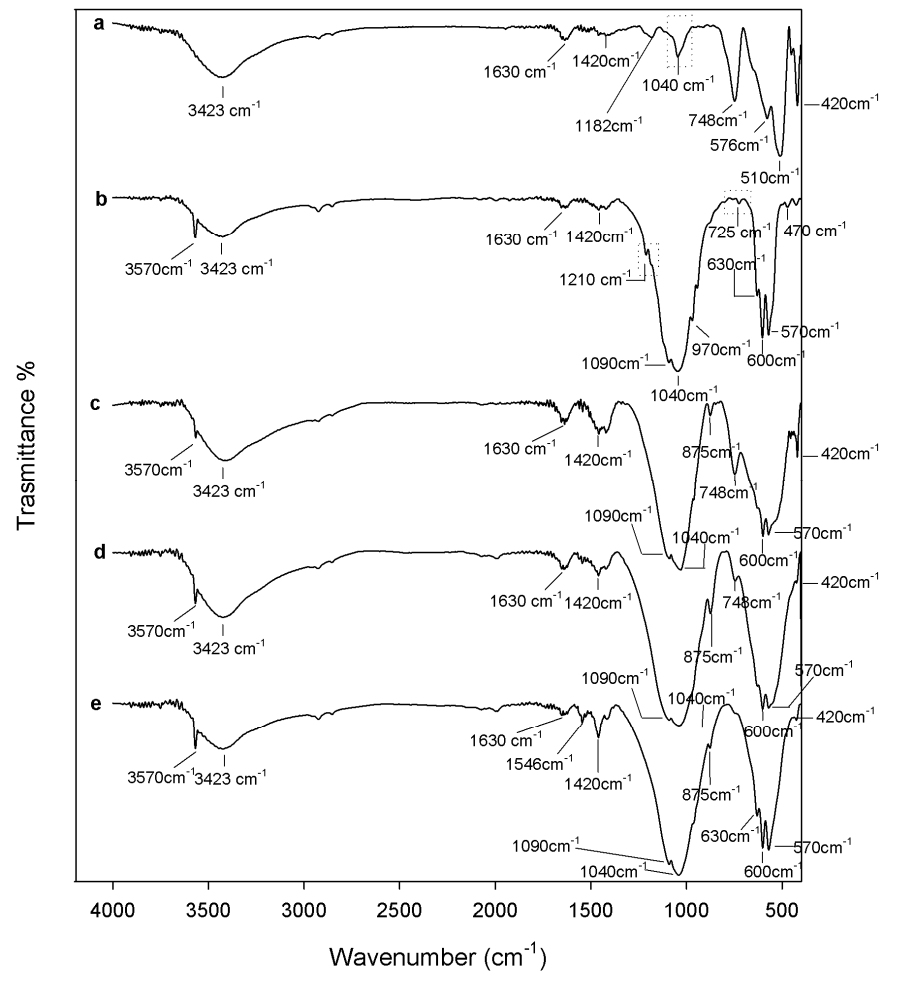

Figure 8. FTIR of (a) $\mathrm{ZrO}_{2}$; (b) $\mathrm{HAp}$; (c) $9 \mathrm{ZrO}_{2} \cdot 1 \mathrm{Hap}$; (d) $7 \mathrm{ZrO}_{2} \cdot 3 \mathrm{Hap}$; and (e) $5 \mathrm{ZrO}_{2} \cdot 5 \mathrm{HAp}$ gels, heated to $1000^{\circ} \mathrm{C}$, after 21 days of exposure to SBF.

SEM/EDX (Energy Dispersive X-ray analysis) of the sample disks (Figure 9) confirmed FTIR results. On the surface of all samples the formation of a precipitate with a globular shape typical of HAp is visible (Figure 9). EDX analysis (Figure 10) of such globules show that they consist of an atomic ratio $\mathrm{Ca} / \mathrm{P}<1.67$, identifying them as calcium-deficient HAp [69]. Therefore, all the synthesized materials are bioactive. However, on the surface of the $600^{\circ}$-heated samples only a few globules are visible, whereas the surface of the $1000^{\circ}$-heated samples, except to $\mathrm{ZrO}_{2}$, appears entirely covered by the HAp globule, confirming that $1000{ }^{\circ} \mathrm{C}$ heating improves the material's bioactivity. The improvement of the bioactivity and the increase of the carbonatation process, recorded when the temperature of the heat treatment was increased from $600{ }^{\circ} \mathrm{C}$ to $1000{ }^{\circ} \mathrm{C}$, can be ascribed to the different ion release degree caused by the different crystallinity degree of the materials. As already discussed above, in fact, the 
increase of crystallization, due to the $1000^{\circ} \mathrm{C}$ heating, causes the decrease of the ion release in the SBF. The ion exchange, which occurs in the solution containing the $600{ }^{\circ} \mathrm{C}$ heated materials, is different from that which takes place in the solution containing the samples heated to $1000{ }^{\circ} \mathrm{C}$. Therefore, the different ion exchange results in a different surface material charge and in a different $\mathrm{pH}$ of the SBF solution. The combination of those factors can modify the kinetic of both the nucleation reaction of HAp and of the $\mathrm{CO}_{2}$ solubilization process in SBF and, thus, of the carbonatation reaction. In the literature $[45,70]$, the presence of a relationship between the heat treatment of the materials and the nucleation of the carbonated HAp was already observed and ascribed mainly to the increase of solution $\mathrm{pH}$, due to the release of $\mathrm{Ca}^{2+}$ and $\mathrm{PO}_{4}{ }^{3-}$ ions [45].

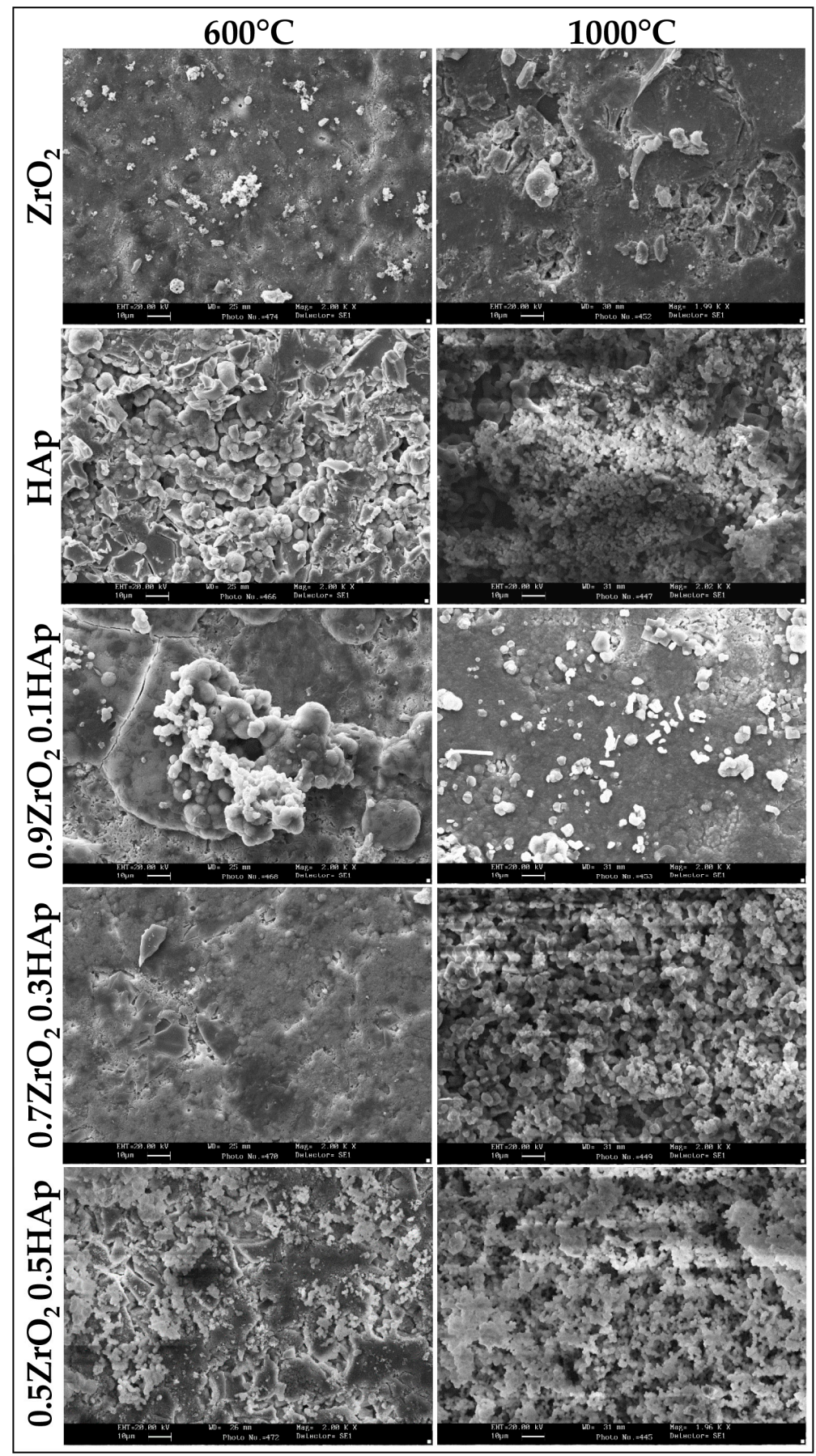

Figure 9. SEM images of all samples heated to $600{ }^{\circ} \mathrm{C}$ and $1000^{\circ} \mathrm{C}$ after 21 days of exposure to SBF. 


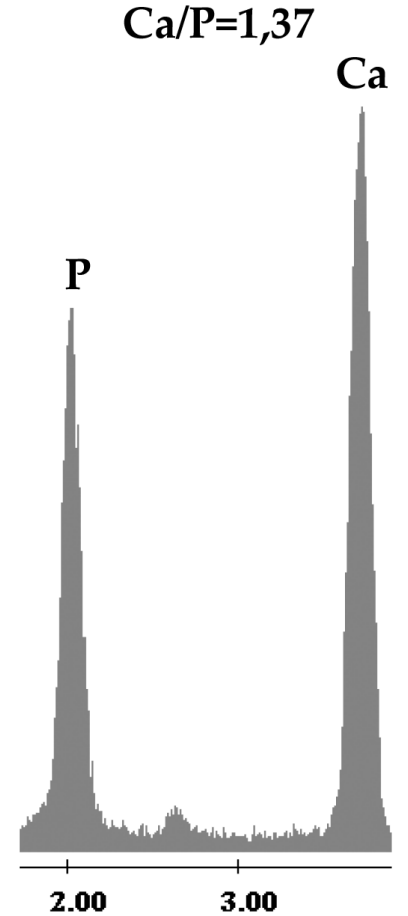

(a)
$\mathrm{Ca} / \mathrm{P}=1,41$

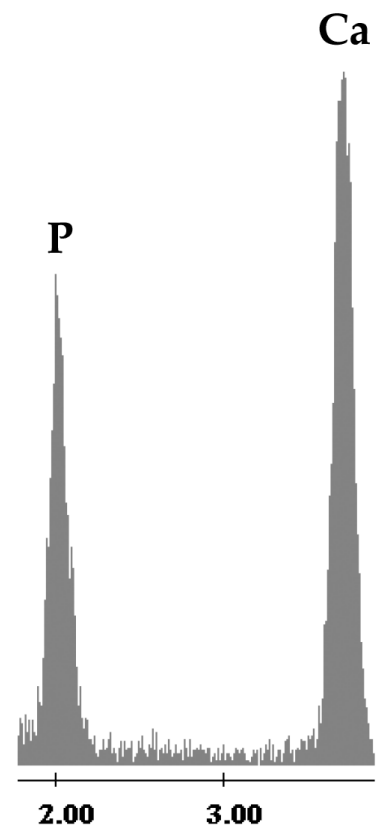

(b)

Figure 10. Representative Energy Dispersive X-ray analysis (EDX) images of the globular precipitate on the surface of the samples heated to (a) $600{ }^{\circ} \mathrm{C}$ and (b) $1000{ }^{\circ} \mathrm{C}$ after 21 days of exposure to SBF.

Moreover, the SEM images showed that the pure HAp sample is more bioactive than pure $\mathrm{ZrO}_{2}$, and the higher the HAp content in the $\mathrm{xZrO}_{2} \cdot(1-\mathrm{x}) \mathrm{HAp}$ composites, the higher the material's bioactivity. This is ascribable mainly to the presence of $\mathrm{Ca}^{2+}$ ions. It is reported in the literature that a higher content of cation in the materials can induce HAp nucleation. The cations can be exchanged with the $\mathrm{H}^{+}$in the SBF solution. The increase of the $\mathrm{pH}$ value of the solution leads to the dissociation of the -OH groups on the surface of the sol-gel materials and a higher amount of negatively charged $-\mathrm{O}^{-}$, able to induce HAp nucleation.

\section{Materials and Methods}

\subsection{Sol-Gel Synthesis of the Composites}

The sol-gel method was used to synthesize $\mathrm{xZrO}_{2}(1-\mathrm{x}) \mathrm{HAp}$ composites, where $\mathrm{x}$ is the mole fraction of $\mathrm{ZrO}_{2}$ in the composites and is equal to $1,0.9,0.7,0.5$, and 0 . All reagents were obtained from Sigma Aldrich (Milan, Italy). To synthesize the pure $\mathrm{ZrO}_{2}$ sample $(\mathrm{x}=1)$, a zirconium propoxide solution (70 wt. \% in 1-propanol) was used as precursor. The metal alkoxide was added to a solution of acetyl acetone (AcAc) in ethanol $99.8 \%$. The AcAc was added to act as inhibitor of the fast hydrolytic activity of zirconium propoxide. In the obtained sol the reagents had the following molar ratios: $\mathrm{Zr}\left(\mathrm{OCH}_{2} \mathrm{CH}_{2} \mathrm{CH}_{3}\right)_{4} / \mathrm{AcAc}=3$ and $\mathrm{EtOH} / \mathrm{Zr}\left(\mathrm{OCH}_{2} \mathrm{CH}_{2} \mathrm{CH}_{3}\right)_{4}=6$.

To synthesize the pure HAp sample $(\mathrm{x}=0)$ two solutions were prepared, as follows:

1. Calcium nitrate tetrahydrate $\left(\mathrm{Ca}\left(\mathrm{NO}_{3}\right)_{2} \cdot 4 \mathrm{H}_{2} \mathrm{O}\right)$ was dissolved in ethanol $99.8 \%$ under stirring;

2. Phosphorus pentoxide was added to a solution of $\mathrm{NH}_{4} \mathrm{OH}$ in Ethanol with $\mathrm{pH}=11$ under stirring.

When both the solutions were prepared, solution 1 was added to solution 2 under stirring. Within the obtained sol, the molar ratio $\mathrm{Ca} / \mathrm{P}$ was equal to 1.67 .

To synthesize the composites samples, the suitable amount of HAp sol (prepared as described above) was added drop by drop to $\mathrm{ZrO}_{2}$ sol under stirring. All obtained sols, homogeneous and 
transparent, were left to gel at room temperature. The gels were dried at $120^{\circ} \mathrm{C}$ for $2 \mathrm{~h}$ and then heat treated at $600{ }^{\circ} \mathrm{C}$ and $1000{ }^{\circ} \mathrm{C}$ for $2 \mathrm{~h}$.

A schematic representation of the sol-gel synthesis is shown in Figure 11.

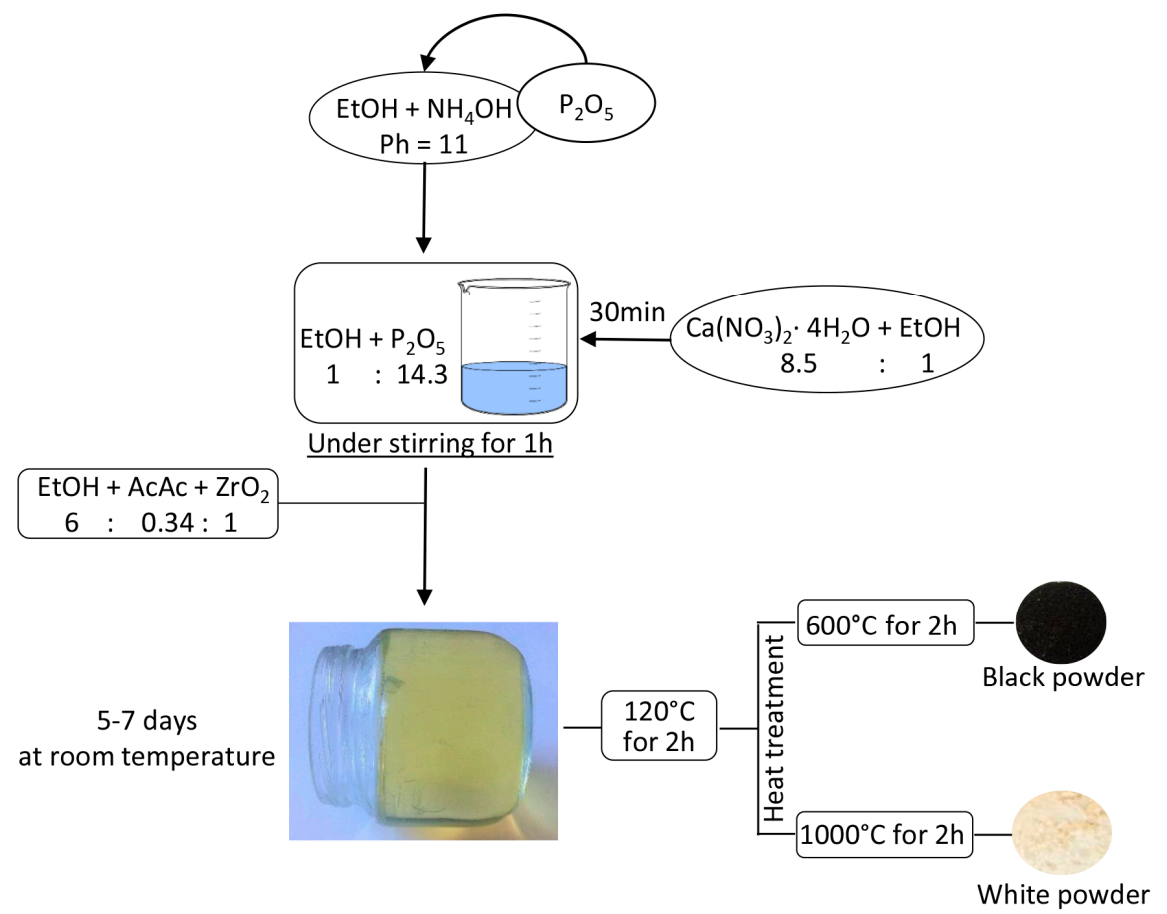

Figure 11. Flow chart of the sol-gel synthesis and heat treatments.

\subsection{Composites Chemical Structure}

The investigation of the chemical structure of the obtained composites was carried out on all the prepared samples after each heat treatment, in order to follow the evolution of the systems as a function of both the temperature and the relative amount of HAp in the composites.

Synthesized composites were analyzed using FTIR. Prestige 21 spectrophotometer (Shimadzu, Tokyo, Japan) was used to record transmittance spectra in the $400-4000 \mathrm{~cm}^{-1}$ region with a resolution of $4 \mathrm{~cm}^{-1}$ (45 scans). The instrument was equipped with a DTGS KBr (Deuterated Tryglycine Sulphate with potassium bromide windows) detector. Pelleted disks containing $2 \mathrm{mg}$ of sample diluted with $\mathrm{KBr}$ ( sample to KBr ratio = 1:100) were made. FTIR spectra were analyzed by Prestige software (IRsolution).

\subsection{Biological Properties}

\subsubsection{Protein Adsorption Evaluation}

In order to evaluate the ability of the materials to interact with the blood proteins (the first step of the cell adhesion process), $10 \mathrm{mg} / \mathrm{mL}$ of each of the sample powders were soaked for $24 \mathrm{~h}$ in a solution of BSA, in a phosphate buffer with $2 \mathrm{mg} / \mathrm{mL}$ concentration. After soaking, the powders were gently rinsed three times with distilled water, and were dried at room temperature in a glass desiccator for $24 \mathrm{~h}$. To evaluate the effective adsorption of the albumin on the materials, the dried powders were then analyzed by means of FTIR spectroscopy to assess the presence of the main peak of the albumin, at $1654 \mathrm{~cm}^{-1}$ (stretching of C-O in amide I) and at $1543 \mathrm{~cm}^{-1}$ (N-H in-plane bending of amide II) [64].

\subsubsection{WST-8 Assay}

Cytotoxicity evaluation was performed using the WST-8 assay (Dojindo Molecular Technologies Inc., MD, USA), a colorimetric assay. The extracted materials were obtained by incubating $150.0 \mathrm{mg}$ of 
the sample powders for $2 \mathrm{~h}$, in $7.5 \mathrm{~mL}$ of a complete culture medium, at $37^{\circ} \mathrm{C}$ under continuous stirring. The NIH-3T3 murine fibroblast cell line (ATCC, Manassas VA, USA) was used in this cytotoxicity test. The cell line was grown in DMEM medium (Gibco, Gaithersburg, MD, USA) with $10 \%(v / v)$ fetal bovine serum ( $1 \%$ pen-strep) in a humidified incubator, at $37{ }^{\circ} \mathrm{C}$ and $5 \% \mathrm{CO}_{2}$. Cells were seeded into 96 multiwell plates at a density of $5.0 \times 10^{3}$ cells/well. After $24 \mathrm{~h}$ of incubation, cells were treated with the extracts for $24 \mathrm{~h}$. Afterwards, they were washed 3 times with PBS (phosphate buffered saline) and again incubated with $10 \% v / v$ of WST-8 [2-(2-methoxy-4-nitrophenyl)-3(4-nitrophenyl)-5-(2,4-disulfophenyl)-2H-tetrazolium, monosodium salt] in a fresh medium for $2 \mathrm{~h}$. (the water-soluble purple-coloured WST-8 tetrazolium salt is able to penetrate the cellular membrane, and is cleaved by mitochondrial dehydrogenases of the live cells, producing insoluble yellow-orange crystals of formazan). The quantification of the generated formazan can be carried out measuring the absorbance, at $450 \mathrm{~nm}$, of the well-plates, which is proportional to the number of viable cells. The absorbance value was measured with a UV-visible spectrophotometer (Biomate 3, Thermo Scientific, Walkersville, MD, USA). A low absorbance value means that the materials in contact with the cells are cytotoxic agents, able to inhibit their mitochondrial activity. Cell viability was expressed as a percentage of mitochondrial redox activity of the cells directly exposed to material extracts, compared to that of an unexposed control. Therefore, the value of the cell viability has been expressed as the percentage of UV absorbance at $450 \mathrm{~nm}$, recorded in the well where the cells treated with the sample extracts were seeded (compared to the absorbance recorded in the well where untreated control cells where seeded, considered as $100 \%$ of viability). The percentages of cell viability were calculated as an average of 3 determinations \pm the standard deviation.

\subsubsection{Apatite-Forming Ability Test}

For evaluations of in vitro bioactivity, the apatite-forming ability test was carried out, as proposed by Kokubo et al. [19]. Both the sample powders and sample disks (13 $\mathrm{mm}$ of diameter and $2 \mathrm{~mm}$ of thickness), obtained by sample powder pressing, were soaked for 21 days in a SBF with an ion concentration nearly equal to that in the human blood plasma. Polystyrene bottles containing powder and SBF were placed in a water bath at $37.5 \pm 0.5{ }^{\circ} \mathrm{C}$. As the ratio between the exposed sample surface and the SBF volume affects the test, it was chosen for the powders and the disks in accordance with Catauro et al. [45] and Kokubo et al. [71], respectively, and kept constant. As the exposed surface area of the powders is higher than the one of the sample disks, a higher volume of SBS was used to test the bioactivity of the sample powders compared to the SBS volume used to test the sample disks.

The solution was replaced every 2 days to avoid depletion of the ionic species in the SBF, due to the nucleation of biominerals on the samples.

After each exposure time, the samples, as powders and as disks, were removed from SBF, gently washed with deionized water, and dried in a desiccator. The hydroxyapatite deposition on the powders was evaluated by FTIR spectroscopy, whereas on the disks it was evaluated by SEM(SEM Quanta 200, FEI, Eindhoven, The Netherlands), equipped with an EDX.

\section{Conclusions}

The sol-gel technique allowed the preparation of $\mathrm{ZrO}_{2}$-based composites containing different amounts of HAp. Modification of the materials' structure was induced by heating $\left(120^{\circ} \mathrm{C}, 600{ }^{\circ} \mathrm{C}\right.$, and $1000^{\circ} \mathrm{C}$ ), and was followed by FTIR analysis of all samples after each heat treatment. Moreover, biological properties of the synthesized materials were tested in vitro as a function of heat treatment and HAp content. The results showed that HAp content does not influence the composites' ability to adsorb blood proteins or their cytotoxicity, but improves the materials' bioactivity. In contrast, the heat treatment acts on all the tested biological properties and, in particular, $1000{ }^{\circ} \mathrm{C}$ heating allowed a higher performance improvement than $600^{\circ} \mathrm{C}$ heating.

Therefore, the results of the reported preliminary tests encourage performing, in the future, more extensive analysis on cells attachment, proliferation, and viability. A more extensive biological 
characterization will be needed to fully understand the behavior of the synthesized materials in vitro, and to identify the cell-materials' interaction mechanism and the effect of such interaction on the cell cycle.

Author Contributions: Flavia Bollino conceived and designed the experiments. Moreover, she coordinated the experimental activity, analyzed data and wrote the paper. Elisabetta Tranquillo and Emilia Armenia, coordinated by Flavia Bollino, performed the experiments. The former carried out the synthesis of the materials and the FTIR analyses while the latter was dealing with the cell culture and WST-8 assay.

Conflicts of Interest: The authors declare no conflict of interest.

\section{References}

1. Abd El-Ghany, O.S.; Sherief, A.H. Zirconia based ceramics, some clinical and biological aspects: Review. Future Dent. J. 2016, 2, 55-64. [CrossRef]

2. Catauro, M.; Bollino, F.; Papale, F.; Pacifico, S.; Galasso, S.; Ferrara, C.; Mustarelli, P. Synthesis of zirconia/polyethylene glycol hybrid materials by sol-gel processing and connections between structure and release kinetic of indomethacin. Drug Deliv. 2014, 21, 595-604. [CrossRef] [PubMed]

3. Harianawala, H.; Kheur, M.; Kheur, S.; Sethi, T.; Bal, A.; Burhanpurwala, M.; Sayed, F. Biocompatibility of Zirconia. J. Adv. Med. Dent. Sci. Res. 2016, 4, 35-39.

4. Catauro, M.; Papale, F.; Bollino, F.; Gallicchio, M.; Pacifico, S. Biological evaluation of zirconia/PEG hybrid materials synthesized via sol-gel technique. Mater. Sci. Eng. C 2014, 40, 253-259. [CrossRef] [PubMed]

5. Ramesh, T.R.; Gangaiah, M.; Harish, P.V.; Krishnakumar, U.; Nandakishore, B. Zirconia Ceramics as a Dental Biomaterial-An Over view. Trends Biomater. Artif. Organs 2012, 26, 154-160.

6. Hannink, R.H.J; Kelly, P.M.; Muddle, B.C. Transformation toughening in zirconia-containing ceramics. J. Am. Ceram. Soc. 2000, 83, 461-487. [CrossRef]

7. Burger, W.; Richter, H.G.; Piconi, C.; Vatteroni, R.; Cittadini, A.; Boccalari, M. New Y-TZP powders for medical grade zirconia. J. Mater. Sci. Mater. Med. 1997, 8, 113-118. [CrossRef] [PubMed]

8. Ruiz, L.; Readey, M.J. Effect of Heat Treatment on Grain Size, Phase Assemblage, and Mechanical Properties of $3 \mathrm{~mol} \%$ Y-TZP. J. Am. Ceram. Soc. 1996, 79, 2331-2340. [CrossRef]

9. Gupta, T.K.; Lange, F.F.; Bechtold, J.H. Effect of stress-induced phase transformation on the properties of polycrystalline zirconia containing metastable tetragonal phase. J. Mater. Sci. 1978, 13, 1464-1470. [CrossRef]

10. Piconi, C.; Maccauro, G. Zirconia as a ceramic biomaterial. Biomaterials 1999, 20, 1-25. [CrossRef]

11. Evans, A.G.; Heuer, A.H. Review-Transformation Toughening in Ceramics: Martensitic Transformations in Crack-Tip Stress Fields. J. Am. Ceram. Soc. 1980, 63, 241-248. [CrossRef]

12. Coli, P.; Karlsson, S. Fit of a New Pressure-Sintered Zirconium Dioxide Coping. Int. J. Prosthodont. 2004, 17, 59-64. [PubMed]

13. Salehi, S.; Fathi, M.H. Fabrication and characterization of sol-gel derived hydroxyapatite/zirconia composite nanopowders with various yttria contents. Ceram. Int. 2010, 36, 1659-1667. [CrossRef]

14. Qiu, D.; Wang, A.; Yin, Y. Characterization and corrosion behavior of hydroxyapatite/zirconia composite coating on NiTi fabricated by electrochemical deposition. Appl. Surf. Sci. 2010, 257, 1774-1778. [CrossRef]

15. Say, Y.; Aksakal, B. Effects of hydroxyapatite/Zr and bioglass/ $\mathrm{Zr}$ coatings on morphology and corrosion behaviour of Rex-734 alloy. J. Mater. Sci. Mater. Med. 2016, 27, 105. [CrossRef] [PubMed]

16. Kong, D.-J.; Long, D.; Wu, Y.-Z.; Zhou, C.-Z. Mechanical properties of hydroxyapatite-zirconia coatings prepared by magnetron sputtering. Trans. Nonferrous Met. Soc. China 2012, 22, 104-110. [CrossRef]

17. Hench, L.L. Bioceramics. J. Am. Ceram. Soc. 1998, 81, 1705-1728. [CrossRef]

18. Catauro, M.; Bollino, F.; Papale, F.; Pacifico, S. Modulation of indomethacin release from $\mathrm{ZrO}_{2} / \mathrm{PCL}$ hybrid multilayers synthesized via sol-gel dip coating. J. Drug Deliv. Sci. Technol. 2015, 26, 10-16. [CrossRef]

19. Catauro, M.; Bollino, F.; Papale, F. Biocompatibility improvement of titanium implants by coating with hybrid materials synthesized by sol-gel technique. J. Biomed. Mater. Res. Part A 2014, 102, 4473-4479. [CrossRef] [PubMed]

20. Catauro, M.; Bollino, F.; Papale, F. Preparation, characterization, and biological properties of organic-inorganic nanocomposite coatings on titanium substrates prepared by sol-gel. J. Biomed. Mater. Res. Part A 2014, 102, 392-399. [CrossRef] [PubMed] 
21. Catauro, M.; Bollino, F.; Papale, F.; Giovanardi, R.; Veronesi, P. Corrosion behavior and mechanical properties of bioactive sol-gel coatings on titanium implants. Mater. Sci. Eng. C 2014, 43, 375-382. [CrossRef] [PubMed]

22. Catauro, M.; Bollino, F.; Papale, F.; Mozetic, P.; Rainer, A.; Trombetta, M. Biological response of human mesenchymal stromal cells to titanium grade 4 implants coated with $\mathrm{PCL} / \mathrm{ZrO}_{2}$ hybrid materials synthesized by sol-gel route: In vitro evaluation. Mater. Sci. Eng. C 2014, 45, 395-401. [CrossRef] [PubMed]

23. Faure, J.; Drevet, R.; Lemelle, A.; Ben Jaber, N.; Tara, A.; El Btaouri, H.; Benhayoune, H. A new sol-gel synthesis of $45 S 5$ bioactive glass using an organic acid as catalyst. Mater. Sci. Eng. C 2015, 47, 407-412. [CrossRef] [PubMed]

24. Catauro, M.; Laudisio, G.; Costantini, A.; Fresa, R.; Branda, F. Low Temperature Synthesis, Structure and Bioactivity of $2 \mathrm{CaO} \cdot 3 \mathrm{SiO}_{2}$ Glass. J. Sol-Gel Sci. Technol. 1997, 10, 231-237. [CrossRef]

25. Pirayesh, H.; Nychka, J.A. Sol-Gel Synthesis of Bioactive Glass-Ceramic 45S5 and its in vitro Dissolution and Mineralization Behavior. J. Am. Ceram. Soc. 2013, 96, 1643-1650. [CrossRef]

26. Catauro, M.; Bollino, F. Anti-inflammatory entrapment in polycaprolactone/silica hybrid material prepared by sol-gel route, characterization, bioactivity and in vitro release behavior. J. Appl. Biomater. Funct. Mater. 2013, 11, 172-179. [CrossRef] [PubMed]

27. Balamurugan, A.; Sockalingum, G.; Michel, J.; Fauré, J.; Banchet, V.; Wortham, L.; Bouthors, S.; Laurent-Maquin, D.; Balossier, G. Synthesis and characterisation of sol gel derived bioactive glass for biomedical applications. Mater. Lett. 2006, 60, 3752-3757. [CrossRef]

28. Brinker, C.; Scherer, G. Sol-Gel Science: The Physics and Chemistry of Sol-Gel Processing; Academic Press: San Diego, CA, USA, 1989.

29. Gupta, R.; Kumar, A. Bioactive materials for biomedical applications using sol-gel technology. Biomed. Mater. 2008, 3. [CrossRef] [PubMed]

30. Martin, R.A.; Yue, S.; Hanna, J.V.; Lee, P.D.; Newport, R.J.; Smith, M.E.; Jones, J.R. Characterizing the hierarchical structures of bioactive sol-gel silicate glass and hybrid scaffolds for bone regeneration. Philos. Trans. R. Soc. A Math. Phys. Eng. Sci. 2012, 370, 1422-1443. [CrossRef] [PubMed]

31. Sepulveda, P.; Jones, J.R.; Hench, L.L. Characterization of melt-derived $45 S 5$ and sol-gel-derived $58 \mathrm{~S}$ bioactive glasses. J. Biomed. Mater. Res. 2001, 58, 734-740. [CrossRef] [PubMed]

32. Picquart, M.; López, T.; Gómez, R.; Torres, E.; Moreno, A.; Garcia, J. Dehydration and crystallization process in sol-gel zirconia. J. Therm. Anal. Calorim. 2004, 76, 755-761. [CrossRef]

33. Agrawal, K.; Singh, G.; Puri, D.; Prakash, S. Synthesis and Characterization of Hydroxyapatite Powder by Sol-Gel Method for Biomedical Application. J. Miner. Mater. Charact. Eng. 2011, 10, 727-734. [CrossRef]

34. Mutlu, H.I.; Hascicek, Y.S. Insulation for Wind and React High Temperature Superconducting Coils. In Advances in Cryogenic Engineering Materials; Balachandran, U.B., Gubser, D.G., Hartwig, K.T., Reed, R., Warnes, W.H., Bardos, V.A., Eds.; Springer Science + Business Media, LLC: New York, NY, USA, 1998.

35. Wachsman, E.D.; Henn, F.E.G.; Jiang, N.; Leezenberg, P.B.; Buchanan, R.M.; Frank, C.W.; Stevenson, D.A.; Wenckus, J.F. Luminescence of Anion Vacancies and Dopant-Vacancy Associated in Stabilized Zirconia. In Science and Technology of Zirconia V; Badwal, S.P.S., Bannister, M.J., Hannink, R.H.J., Eds.; Technomic Publishing Company: Lancaster, PA, USA, 1993; pp. 584-592.

36. Catauro, M.; Bollino, F.; Papale, F.; Mozzati, M.C.; Ferrara, C.; Mustarelli, P. ZrO $2 /$ PEG hybrid nanocomposites synthesized via sol-gel: Characterization and evaluation of the magnetic properties. J. Non-Cryst. Solids 2015, 413, 1-7. [CrossRef]

37. Santos, V.; Zeni, M.; Bergmann, C.; Hohemberger, J. Correlation between thermal treatment and tetragonal/monoclinic nanostructured zirconia powder obtained by sol-gel process. Rev. Adv. Mater. Sci. 2008, 17, 62-70.

38. Petkova, N.; Dlugocz, S.; Gutzov, S. Preparation and optical properties of transparent zirconia sol-gel materials. J. Non-Cryst. Solids 2011, 357, 1547-1551. [CrossRef]

39. Georgieva, I.; Danchova, N.; Gutzov, S.; Trendafilova, N. DFT modeling, UV-Vis and IR spectroscopic study of acetylacetone-modified zirconia sol-gel materials. J. Mol. Model 2012, 18, 2409-2422. [CrossRef] [PubMed]

40. Elvira, M.R.; Mazo, M.A.; Tamayo, A.; Rubio, F.; Rubio, J.; Oteo, J.L. Study and characterization of organically modified silica-zirconia anti-Graffiti coatings obtained by sol-gel. J. Chem. Chem. Eng. 2013, 7, 120-131.

41. Hao, Y.; Li, J.; Yang, X.; Wang, X.; Lu, L. Preparation of $\mathrm{ZrO}_{2}-\mathrm{Al}_{2} \mathrm{O}_{3}$ composite membranes by sol-gel process and their characterization. Mater. Sci. Eng. A 2004, 367, 243-247. [CrossRef] 
42. Irish, D.E.; Walrafen, G.E. Raman and infrared spectral studies of aqueous calcium nitrate solutions. J. Chem. Phys. 1967, 46, 378-384. [CrossRef]

43. Brauer, D.S. Phosphate glass. In Bio-Glasses: An Introduction; Jones, J.R., Clare, A.G., Eds.; John Wiley \& Sons, Ltd.: Oxford, UK, 2012; pp. 46-49.

44. De Oliveira, A.A.; de Souza, D.A.; Dias, L.L.; de Carvalho, S.M.; Mansur, H.S.; de Magalhães Pereira, M. Synthesis, characterization and cytocompatibility of spherical bioactive glass nanoparticles for potential hard tissue engineering applications. Biomed. Mater. 2013, 8. [CrossRef] [PubMed]

45. Catauro, M.; Bollino, F.; Renella, R.A.; Papale, F. Sol-gel synthesis of $\mathrm{SiO}_{2}-\mathrm{CaO}-\mathrm{P}_{2} \mathrm{O}_{5}$ glasses: Influence of the heat treatment on their bioactivity and biocompatibility. Ceram. Int. 2015, 41, 12578-12588. [CrossRef]

46. Brangule, A.; Gross, K.A. Importance of FTIR Spectra Deconvolution for the Analysis of Amorphous Calcium Phosphates; IOP Conference Series: Materials Science and Engineering; IOP Publishing Ltd.: Bristol, UK, 2015.

47. Kurajica, S.; Lozić, I.; Pantaler, M. Thermal decomposition of calcium(II) bis(acetylacetonate) n-hydrate. Polimeri 2015, 35, 4-9.

48. Li, P.; Ohtsuki, C.; Kokubo, T.; Nakanishi, K.; Soga, N.; Nakamura, T.; Yamamuro, T. Process of formation of bone-like apatite layer on silica gel. J. Mater. Sci. Mater. Med. 1993, 4, 127-131. [CrossRef]

49. Ohtsuki, C.; Kokubo, T.; Yamamuro, T. Mechanism of apatite formation on CaOSiO2P2O5 glasses in a simulated body fluid. J. Non-Cryst. Solids 1992, 143, 84-92. [CrossRef]

50. Beganskienè, A.; Dudko, O.; Sirutkaitis, R.; Giraitis, R. Water Based Sol-Gel Synthesis of Hydroxyapatite. Mater. Sci. 2003, 9, 383-386.

51. Vecchio Ciprioti, S.; Bollino, F.; Tranquillo, E.; Catauro, M. Synthesis, thermal behavior and physicochemical characterization of $\mathrm{ZrO} / \mathrm{PEG}$ inorganic/organic hybrid materials via sol-gel technique. J. Therm. Anal. Calorim. 2017, 1-6. [CrossRef]

52. Jayakumar, S.; Ananthapadmanabhan, P.V.; Perumal, K.; Thiyagarajan, T.K.; Mishra, S.C.; Su, L.T.; Tok, A.I.Y.; Guo, J. Characterization of nano-crystalline $\mathrm{ZrO} 2$ synthesized via reactive plasma processing. Mater. Sci. Eng. B 2011, 176, 894-899. [CrossRef]

53. Chen, S.; Yin, Y.; Wang, D.; Liu, Y.; Wang, X. Structures, growth modes and spectroscopic properties of small zirconia clusters. J. Cryst. Growth 2005, 282, 498-505. [CrossRef]

54. Berzina-Cimdina, L.; Borodajenko, N. Research of Calcium Phosphates Using Fourier Transform Infrared Spectroscopy. In Infrared Spectroscopy—Materials Science, Engineering and Technology; Theophile, T., Ed.; InTech: Rijeka, Croatia, 2012; pp. 123-148.

55. Gozalian, A.; Behnamghader, A.; Daliri, M.; Moshkforoush, A. Synthesis and thermal behavior of Mg-doped calcium phosphate nanopowders via the sol gel method. Sci. Iran. 2011, 18, 1614-1622. [CrossRef]

56. Meejoo, S.; Maneeprakorn, W.; Winotai, P. Phase and thermal stability of nanocrystalline hydroxyapatite prepared via microwave heating. Thermochim. Acta 2006, 447, 115-120. [CrossRef]

57. Fleet, M.E.; Liu, X.; King, P.L. Accommodation of the carbonate ion in apatite: An FTIR and X-ray structure study of crystals synthesized at 2-4 GPa. Am. Mineral. 2004, 89, 1422-1432. [CrossRef]

58. Eichert, D.; Drouet, C.; Sfihi, H.; Rey, C.; Combes, C. Nanocrystalline apatite-based biomaterials: Synthesis, processing and characterization. In Biomaterials Research Advances; Kendall, J.B., Ed.; Nova Science Publishers: New York, NY, USA, 2007; pp. 93-143.

59. Barralet, J.; Knowles, J.C.; Best, S.; Bonfield, W. Thermal decomposition of synthesised carbonate hydroxyapatite. J. Mater. Sci. Mater. Med. 2002, 13, 529-533. [CrossRef] [PubMed]

60. Latifi, S.M.; Fathi, M.; Varshosaz, J.; Ghochaghi, N. Mechanisms controlling ca ion release from sol-gel derived in situ apatite-silica nanocomposite powder. Ceram. Silik. 2015, 59, 64-69.

61. Mansour, S.F.; El-dek, S.I.; Ahmed, M.K. Physico-mechanical and morphological features of zirconia substituted hydroxyapatite nano crystals. Sci. Rep. 2017, 7. [CrossRef] [PubMed]

62. Mortier, A.; Lemaitre, J.; Rouxhet, P.G. Temperature-programmed characterization of synthetic calcium-deficient phosphate apatites. Thermochim. Acta 1989, 143, 265-282. [CrossRef]

63. Kalinkin, A.M.; Kalinkina, E.V.; Zalkind, O.A.; Makarova, T.I. Chemical interaction of calcium oxide and calcium hydroxide with $\mathrm{CO}_{2}$ during mechanical activation. Inorg. Mater. 2005, 41, 1073-1079. [CrossRef]

64. Popescu, R.A.; Magyari, K.; Vulpoi, A.; Trandafir, D.L.; Licarete, E.; Todea, M.; Stefan, R.; Voica, C.; Vodnar, D.C.; Simon, S.; et al. Bioactive and biocompatible copper containing glass-ceramics with remarkable antibacterial properties and high cell viability designed for future in vivo trials. Biomater. Sci. 2016, 4, 1252-1265. [CrossRef] [PubMed] 
65. Mavropoulos, E.; Costa, A.M.; Costa, L.T.; Achete, C.A.; Mello, A.; Granjeiro, J.M.; Rossi, A.M. Adsorption and bioactivity studies of albumin onto hydroxyapatite surface. Coll. Surf. B Biointerfaces 2011, 83, 1-9. [CrossRef] [PubMed]

66. Kumar, R.; Münstedt, H. Polyamide/silver antimicrobials: Effect of crystallinity on the silver ion release. Polym. Int. 2005, 54, 1180-1186. [CrossRef]

67. Ogose, A.; Hotta, T.; Kawashima, H.; Kondo, N.; Gu, W.; Kamura, T.; Endo, N. Comparison of hydroxyapatite and beta tricalcium phosphate as bone substitutes after excision of bone tumors. J. Biomed. Mater. Res. Part $B$ Appl. Biomater. 2005, 72B, 94-101. [CrossRef] [PubMed]

68. Jalota, S.; Bhaduri, S.B.; Tas, A.C. In vitro testing of calcium phosphate (HA, TCP, and biphasic HA-TCP) whiskers. J. Biomed. Mater. Res. Part A 2006, 78A, 481-490. [CrossRef] [PubMed]

69. Catauro, M.; Papale, F.; Sapio, L.; Naviglio, S. Biological influence of Ca/P ratio on calcium phosphate coatings by sol-gel processing. Mater. Sci. Eng. C 2016, 65, 188-193. [CrossRef] [PubMed]

70. Radev, L. Influence of thermal treatment on the structure and in vitro bioactivity of sol-gel prepared CaO-SiO2-P2O5 glass-ceramics. Process. Appl. Ceram. 2014, 8, 155-166. [CrossRef]

71. Kokubo, T.; Takadama, H. How useful is SBF in predicting in vivo bone bioactivity? Biomaterials 2006, 27, 2907-2915. [CrossRef] [PubMed]

(C) 2017 by the authors. Licensee MDPI, Basel, Switzerland. This article is an open access article distributed under the terms and conditions of the Creative Commons Attribution (CC BY) license (http:/ / creativecommons.org/licenses/by/4.0/). 